\title{
BIOLOGICAL AND THERMAL PRETREATMENT OF LIGNOCELLULOSIC MATERIALS FOR ENHANCED BIOGAS PRODUCTION
}

By

Samer Dahahda, BEng, Birzeit University, 2015

\author{
A Major Research Paper \\ presented to Ryerson University
}

\author{
in partial fulfillment of the \\ requirements for the degree of \\ Master of Engineering \\ in the program of \\ Civil Engineering
}

Toronto, Ontario, Canada, 2017

(C) Samer Dahadha, 2017 


\section{AUTHOR'S DECLARATION}

I hereby declare that I am the sole author of this MRP. This is a true copy of the MRP, including any required final revisions.

I authorize Ryerson University to lend this MRP to other institutions or individuals for the purpose of scholarly research.

I further authorize Ryerson University to reproduce this MRP by photocopying or by other means, in total or in part, at the request of other institutions or individuals for the purpose of scholarly research.

I understand that my MRP may be made electronically available to the public. 


\title{
BIOLOGICAL AND THERMAL PRETREATMENT OF LIGNOCELLULOSIC MATERIALS FOR ENHANCED BIOGAS PRODUCTION
}

\author{
Samer Dahadha \\ Master of Engineering, 2017 \\ Civil Engineering \\ Ryerson University
}

\begin{abstract}
The rapid depletion of natural resources and the environmental concerns associated with the use of fossil fuels as the main source of global energy is leading to an increased interest in alternative and renewable energy sources. Lignocellulosic biomass is the most abundant source of organic materials that can be utilized as an energy source. Anaerobic digestion has been proven to be an effective technology for converting organic material into energy products such as biogas. However, the nature of lignocellulosic materials hinders the ability of microorganisms in an anaerobic digestion process to degrade and convert organic material to biogas. Therefore, a pretreatment step is necessary to improve the degradability of lignocellulosic materials and achieve higher biogas yield. Several pretreatment methods have been studied over the past few years including physical, thermal, chemical and biological pretreatment. This paper reviews biological and thermal pretreatment as two main promising methods used to improve biogas production from lignocelluloses. A greater focus is given on enzymatic pretreatment which is one of the promising yet under-researched biological pretreatment method. The paper addresses challenges in degrading lignocellulosic materials and the current status of research to improve biogas yield from lignocelluloses through biological and thermal pretreatment.
\end{abstract}




\section{ACKNOWLEDGMENTS}

I would first like to thank Dr. Elsayed Elbeshbishy for his continuous support and encouragement throughout this project. His guidance and mentorship steered me in the right direction while working on this project and helped me to greatly enhance my research skills.

I would also like to acknowledge Dr. Ahmed El-Rabbany for his support and guidance throughout my Master's program.

I would also like to thank Dr. Amir Abbas Bazyar Lakeh for his positive advice and feedback that helped in the completion of this project. 


\section{TABLE OF CONTENTS}

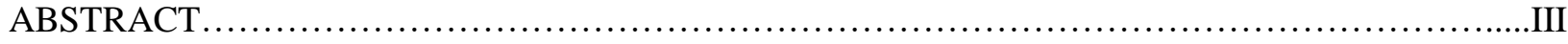

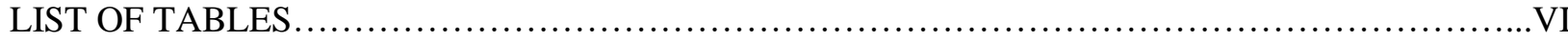

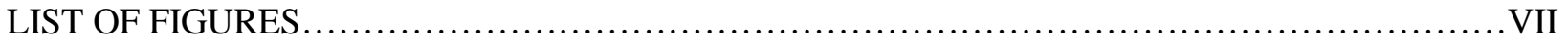

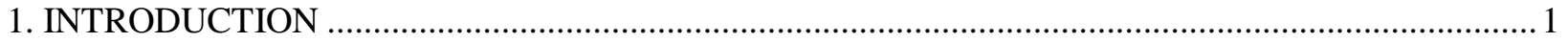

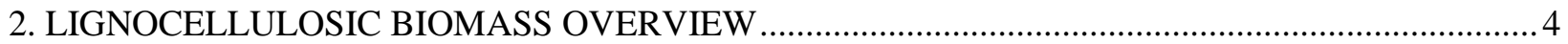

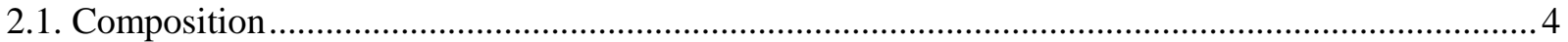

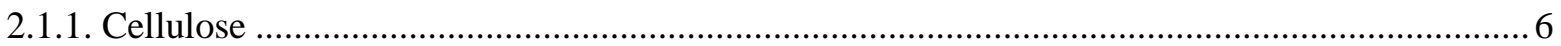

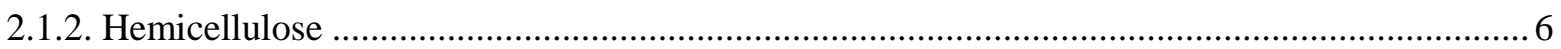

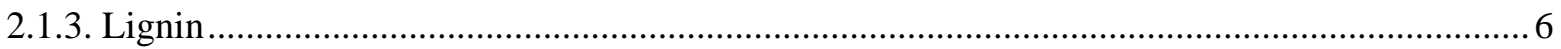

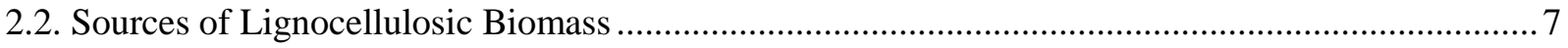

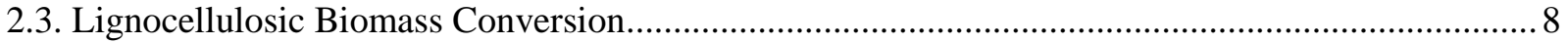

3. ANAEROBIC DIGESTION OF LIGNOCELLULOSIC BIOMASS ….......................................... 10

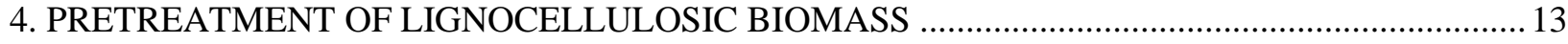

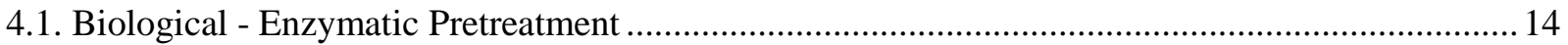

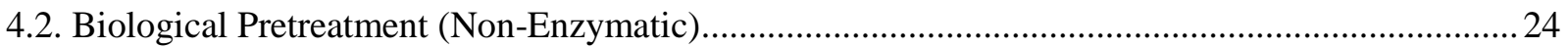

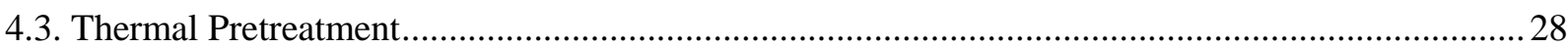

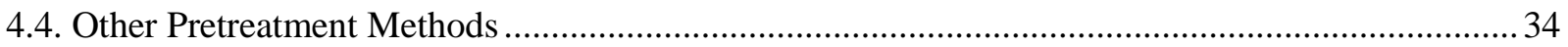

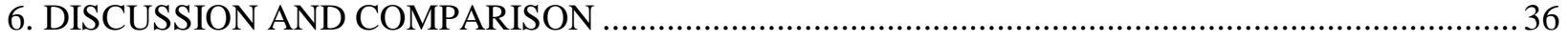

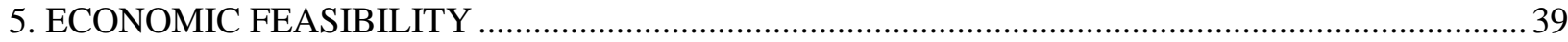

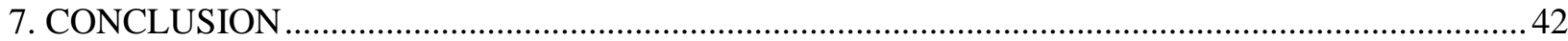

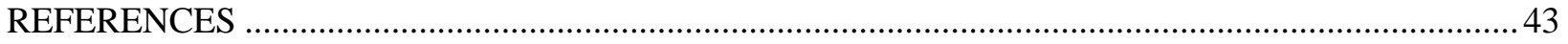




\section{LIST OF TABLES}

Table 1 Composition of certain lignocellulosic biomass from various sources....................................... 5

Table 2 Typical sources and examples of lignocellulosic materials ....................................................... 7

Table 3 Enzymatic pretreatment of lignocellulosic biomass for biogas production in a mesophilic batch reactor.

Table 4 Enzymatic pretreatment of lignocellulosic biomass for biogas production in a thermophilic batch

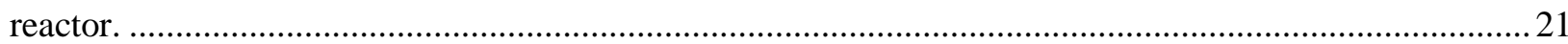

Table 5 Enzymatic pretreatment of lignocellulosic biomass for biogas production in a mesophilic continuous/semi-continuous reactor.

Table 6 Impact of biological pretreatment on methane production from lignocellulosic substrates ..........25

Table 7 Impact of thermal pretreatment on methane production from lignocellulosic substrates ..............29

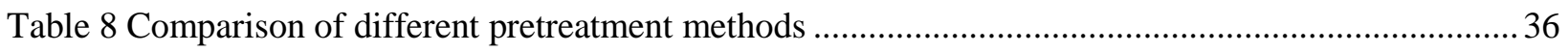




\section{LIST OF FIGURES}

Figure 1. Typical composition of lignocellulosic material. .............................................................. 4

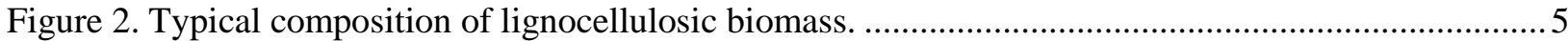

Figure 3. Potential products obtained from lignocellulosic materials through various processes. .............. 8

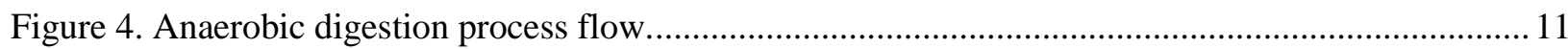

Figure 5. Schematic of pretreating lignocellulosic biomass ................................................................. 13 


\section{INTRODUCTION}

The past decade has witnessed a surge in challenges arising from the increased consumption of fossil fuels and non-renewable energy sources such as the depletion of natural resources and the environmental impact of the use of fossil fuel that contributes to climate change and global warming. It is estimated that more than $84 \%$ of the world's energy demand is supplied through non-renewable sources such as fossil fuels, coal and natural gas [1]. However, such challenges paved a wider way for considering and further researching the use of renewable energy sources and managing natural resources in a sustainable manner. A great amount of research has been dedicated to the use of renewable organic biomass as a more sustainable alternative to fossil fuels and a suitable mean of waste reduction.

A particular interest has been given to lignocellulosic biomasses which are the most abundant source of organic matter on biosphere. Lignocellulosic materials (LCM) are organic materials usually found in plant cell wall [2,3]. Lignocelluloses are composed of a mixture of three main polymers: cellulose, hemicellulose, and lignin that bound together to form the rigid and protective layer of the plant cell wall [1,4]. It can be collected as a waste material from forest, agricultural, industrial, and municipal areas [5]. In addition, Lignocellulosic biomass could be grown as an energy crop that does not compete with food crops and can be planted in areas not suitable for food crops as several ethical concerns have arisen from using food crops such as sugarcane for biofuels production [2,6].

Although lignocellulosic biomass is abundant, there are still many challenges hindering it as an attractive energy source due to the nature and complexity of its components. Lignocellulosic 
materials are often insoluble in water at low temperature and are not easily digestible by most of living organisms including bacteria. This is mainly due to the interaction of the cellulose, hemicellulose, and lignin which form a highly resistant and recalcitrant structure [1,2]. Recent studies have shown that lignocellulosic material makes up about 14 to $44 \%$ of raw excess sludge produced in different wastewater treatment processes indicating the difficulty in digesting it through microorganisms [4].

Anaerobic digestion (AD) of organic matter has proven to be one of the most cost effective and efficient biological processes in treating and converting organic matter to energy in the form of electricity, heat and natural gas [7]. AD is a natural process that relies on microorganisms in digesting organic matter in the absence of oxygen [1]. However, lignocellulosic materials have shown great resistant to anaerobic digestion resulting in low energy yield and digestibility level if introduced to $\mathrm{AD}$ without any pretreatment $[4,7]$. Hydrolysis is often believed to be the rate limiting step in the $\mathrm{AD}$ of lignocelluloses [1,7]. Therefore, to increase the efficiency of $\mathrm{AD}$ in treating lignocellulosic materials and improve energy yield, an efficient pretreatment process is required to enhance the digestibility of lignocellulosic biomass by microorganisms.

Several pretreatment processes have been developed and researched over the past years which could be categorized as physical, thermal, chemical, biological, and combined pretreatment processes [4]. The pretreatment process is essential when handling lignocellulosic material through $\mathrm{AD}$ for a cost efficient and economical conversion. However, this pretreatment step is the most expensive and accounts for about $20 \%$ of the total energy cost yielded from lignocellulosic biomass [8]. Hence, it is important to improve the available pretreatment processes and find new affordable and efficient techniques. 
This paper presents a review of biological and thermal pretreatment of lignocellulosic materials for enhanced biogas production, with focus on enzymatic pretreatment as an emerging pretreatment method that is gaining wider attention in this field. The review includes an overview of lignocelluloses composition and sources, the anaerobic digestion process, a summary of studies available in the literature and the economical aspect of pretreatment. The paper also compares different pretreatment methods and outlines literature limitations and recommended future areas of research. 


\section{LIGNOCELLULOSIC BIOMASS OVERVIEW}

\subsection{Composition}

Lignocellulosic materials are mainly characterized by the presence of three main polymers: lignin, cellulose and hemicellulose in addition to other components found in smaller amounts such as ash, pectin and proteins. Lignocellulose is the main component of plant cell wall which makes LCM as the most abundant organic sources on earth [7,9]. A typical composition of a lignocellulosic material is presented in Figure 1 below.

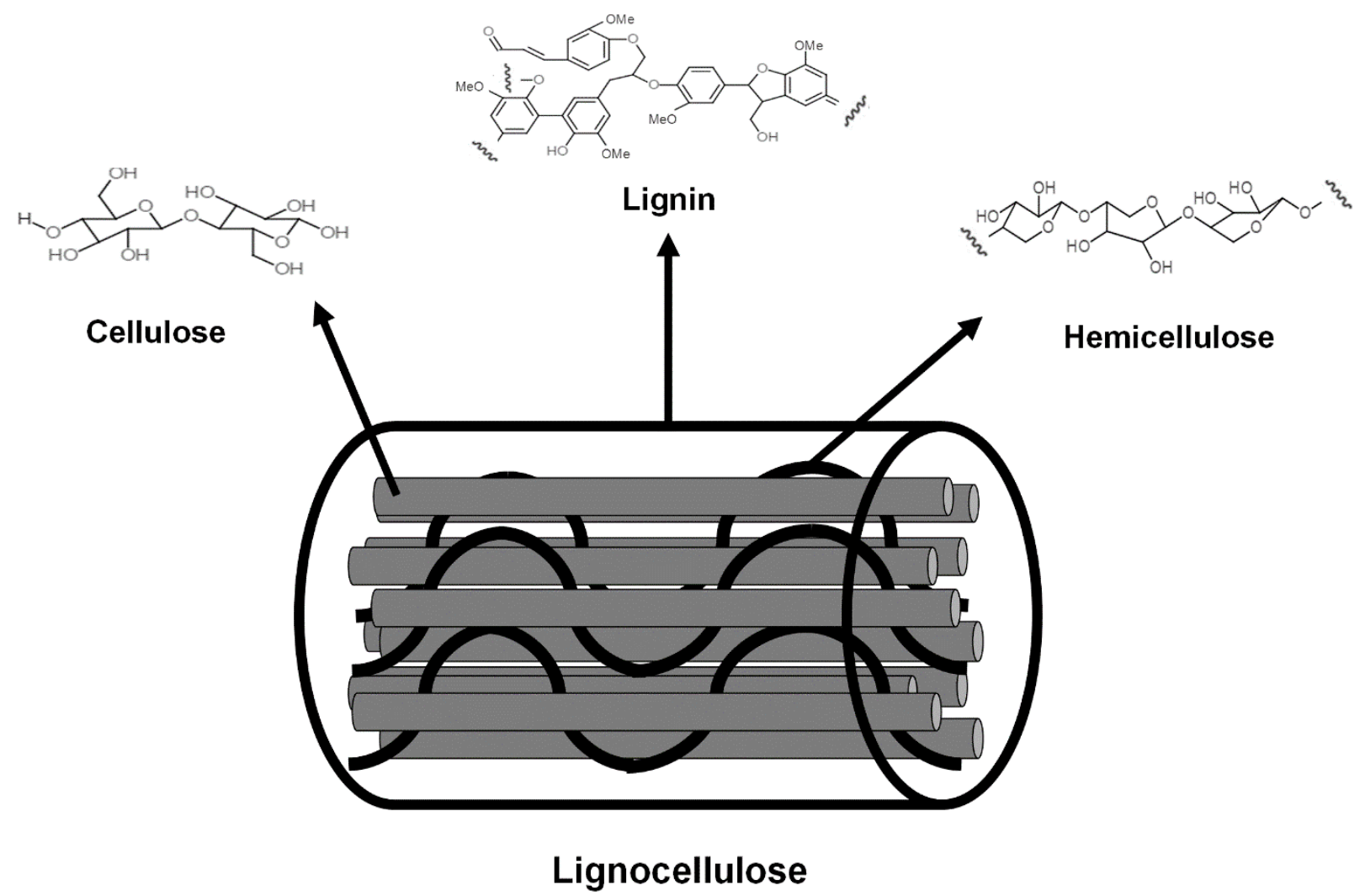

Figure 1. Typical composition of lignocellulosic material (Adapted from ref 10). 
In general, the content of cellulose, hemicellulose, and lignin in lignocellulosic materials is about $30-60 \%, 20-40 \%$ and $15-25 \%$, respectively as shown in Figure $2[1,11,12]$.

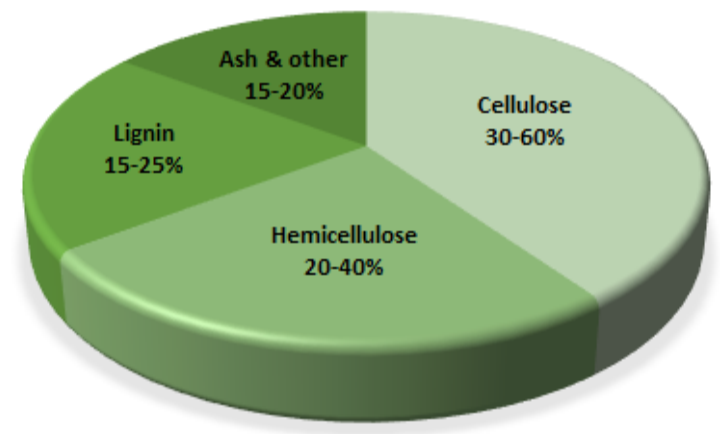

Figure 2 Typical composition of lignocellulosic biomass.

However, different types of lignocellulosic material vary in composition and the percentage content of cellulose, hemicellulose and lignin [1,13]. Table 1 summarizes the average composition of some of the common LCM. The variation in composition is not only present between different species, in fact, varying growth conditions and maturation can also impact the composition of LCM within the same species [1].

Table 1 Composition of different lignocellulosic materials.

\begin{tabular}{lllll}
\hline Lignocellulosic material & Cellulose $(\boldsymbol{\%})$ & Hemicellulose $(\boldsymbol{\%})$ & Lignin $(\boldsymbol{\%})$ & Reference \\
\hline Corn stover & 37.5 & 22.4 & 17.6 & 1,14 \\
Corn cobs & 45 & 35 & 15 & 14 \\
Cotton seed hairs & $80-95$ & $5-20$ & 0 & 14 \\
Switchgrass & $31.0-45$ & $20.0-31.0$ & $12.0-18.0$ & 1,15 \\
Bagasse & 38.2 & 27.1 & 20.2 & 1 \\
Sugarcane & 25.0 & 17.0 & 12.0 & 1 \\
Rice straw & 32.0 & 24.0 & $13-18$ & 1,15 \\
Giant reed stalk & 33.1 & 18.5 & 24.5 & 1 \\
Giant reed leaves & 20.9 & 17.7 & 25.4 & 1 \\
Sunflower stalk & 31.0 & 15.6 & 29.2 & 1 \\
Rye straw & 38.0 & 36.9 & 17.6 & 1 \\
Eucalyptus & $12.0-13.0$ & $25.0-37.0$ & 1 \\
Hardwood stems & $38.0-45.0$ & $24.0-40.0$ & $18-25$ & $14,15,16$ \\
Softwood stems & $40.0-55.0$ & $25-35$ & $25-35$ & $14,15,16$ \\
Nut shells & $45-50$ & $25-30$ & $30-40$ & $14,15,16$ \\
Paper & $25-30$ & 0 & $0-15$ & $14,15,16$ \\
Leaves & $85-99$ & $80-85$ & 0 & $14,15,16$ \\
Newspaper & $15-20$ & $25-40$ & $18-30$ & $14,15,16$ \\
Grasses & $40-55$ & $35-50$ & $10-30$ & $2,14,15,16$ \\
Solid cattle manure & $25-40$ & $1.4-3.3$ & 20 & 14 \\
\hline
\end{tabular}




\subsubsection{Cellulose}

Cellulose is composed of D-glucose subunits linked by $\beta-1,4$ glycosidic bonds and is the main component of most plant cell walls making it as one of the most abundant source of renewable polymers available [5,7]. Cellulose is insoluble in water and many organic solvents. However, it can be dissolved in water at extremely low or high $\mathrm{pH}$ levels as well as other solvents such as ionic liquids (ILSs) and N-methylmorphloine N-oxide (NMMO). The insolubility of cellulose is believed to be a result of the hydrogen bonds holding the crystalline structure $[17,18]$. The characteristics of cellulose make it difficult to be biodegraded or digested by most animals $[5,7,19]$.

\subsubsection{Hemicellulose}

Hemicellulose refers to a family of heteropolymers or polysaccharides that are amorphous and random, and have highly branched structures. There are variable structures of hemicellulose that vary depending on the source of material and extractions method. Hemicellulose is part of the supporting materials in plants cell walls. The composition of hemicellulose is highly variable between different plants and materials. For example, hemicellulose found in hardwood is mainly composed of xylans, while the main component in hemicellulose in softwood is glucomannans $[2,7,16]$. Hemicellulose requires elevated temperatures to become soluble in water with its solubilisation starting at 150 to $180{ }^{\circ} \mathrm{C}$ [19].

\subsubsection{Lignin}

Lignin is the most abundant organic compound after cellulose [7]. It is a complex and large compound made up of phenylpropane units linked in a three-dimensional structure. The main monomers of lignin are p-hydroxyphenyl alcohol, coniferyl alcohol, and sinapyl alcohol [7,14, 21]. Lignin acts as cementing material that links cellulose and hemicellulose to form the rigid three-dimensional structure of plant cell wall [7]. In addition, lignin is optically inactive and 
requires elevated temperatures starting at $180{ }^{\circ} \mathrm{C}$ to dissolve in water [19]. Such properties of lignin makes it the most component in LCM resistant to microbial attacks and biodegradation. Several studies have shown that higher lignin content in LCM increases resistance to biological and chemical degradation $[7,14,20]$.

\subsection{Sources of Lignocellulosic Biomass}

The abundant supply of lignocellulosic biomass could be attributed to its high variety of sources. Lignocellulosic biomass sources can be divided into two main categories which are waste sources and energy crops. Waste sources are those sources where lignocellulosic biomass is produced as a by-product and waste due to different natural and human activities such as forestry and agricultural residues, in addition to municipal solid wastes. Energy crops are those specifically grown as organic feedstocks to produce bioenergy products such as fast-growing trees and switchgrass $[2,22,23]$.

Table 2 Typical sources and examples of lignocellulosic materials (Adapted from Refs 2, 11 and 22).

\begin{tabular}{lll}
\hline Category & Source & Example \\
\hline Waste & Forestry & $\begin{array}{l}\text { Residues resulting from forest logging, harvesting and } \\
\text { other operations. } \\
\text { Corn stover, sugarcane bagasse, wheat straw, rice husk, } \\
\text { pinewood }\end{array}$ \\
Agricultural & Paper waste, paper mill sludge \\
Energy crops & Energy crops & Switchgrass, giant reed and miscanthus \\
\hline
\end{tabular}

The wide range of lignocellulosic biomass contributing to a massive amount of lignocellulosic biomass being produced annually ranks it on top of the list for alternative energy sources despite the several challenges faced in making it an economically viable source for producing energy products [19]. Although there is a contradiction in the literature on the exact amount of global biomass belonging to lignocellulosic biomass some have claimed that annual LCM production is 
estimated at 10 to 50 billion tons annually [24], while others claimed that it is close to 200 billion tons annually [25]. On a smaller scale, lignocellulosic biomass production in the United States has been estimated at 1.4 billion dry tons annually [2].

\subsection{Lignocellulosic Biomass Conversion}

Lignocellulosic material can be utilized to produce various energy products and other potential products. There are many processes that could be applied to convert lignocelluloses to different energy products such as biofuels and biogases. Such processes include anaerobic digestion, fermentation, incineration, pyrolysis, gasification and others [26-28]. Figure 3 presents some of the potential products that could be produced through different processes using lignocellulosic materials as feedstock.

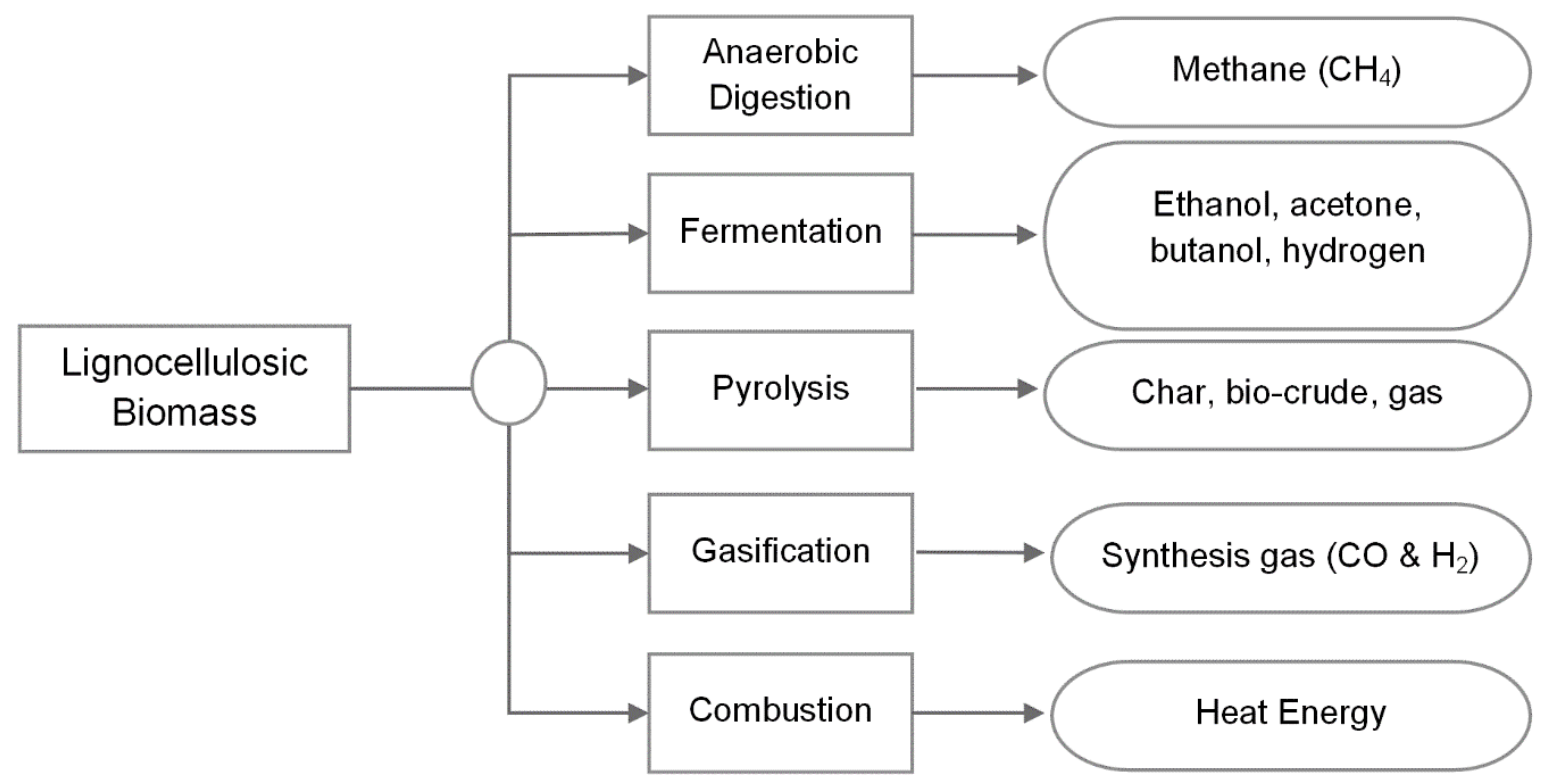

Figure 3. Potential products obtained from lignocellulosic materials through various processes.

However, there remain some obstacles impeding the production of energy from the abundant supply of biomass worldwide. The main challenge is the lack of low-cost technology that would make energy production from biomass an economically feasible process [29]. For this reason, it 
is important to consider the economical aspect of new technologies and methods developed to improve the energy production from lignocellulosic biomass.

The focus of this paper is the $\mathrm{AD}$ as a means of producing biogas (biomethane and carbon dioxide) from lignocellulosic biomass. AD is very common as it relies on the use of microorganisms as an economical energy recovery process. However, as mentioned earlier, the nature of lignocellulosic material hinders the ability of such microorganism to efficiently recover energy from lignocelluloses and thus a process enhancement in the form of pretreatment is necessary to achieve economical feasibility and process sustainability. 


\section{ANAEROBIC DIGESTION OF LIGNOCELLULOSIC BIOMASS}

Anaerobic digestion is a technology proven for its effectiveness and sustainability in treating and converting organic materials into energy products [30,31]. AD relies on microorganism in degrading organic matter and in converting the matter mainly into biogas in the form of methane and carbon dioxide (CO2). The biological degradation of LC material is mainly dependent on enzymes such as hemicellulases and cellulases produced by microorganisms [30].

AD process consists of four main steps (Figure 4): hydrolysis, acidogenesis, acetogenesis and methanogenesis. In the hydrolysis step, extracellular enzymes excreted by hydrolytic microorganisms break down complex organic polymers into simple soluble monomers [7]. Acidogenic or fermentative bacteria then convert the monomers produces to volatile fatty acids and other compounds (e.g alcohol). The fatty acids are then converted by acetogenic bacteria into acetate, carbon dioxide and hydrogen. Finally, methanogenic bacteria in the last step (methanogenesis) converts the products to biogas as a mixture of methane, carbon dioxide and other traces of gas. The percentage of methane in biogas has been reported to fall in the range of 50 to $75 \%[7,32,33]$. 


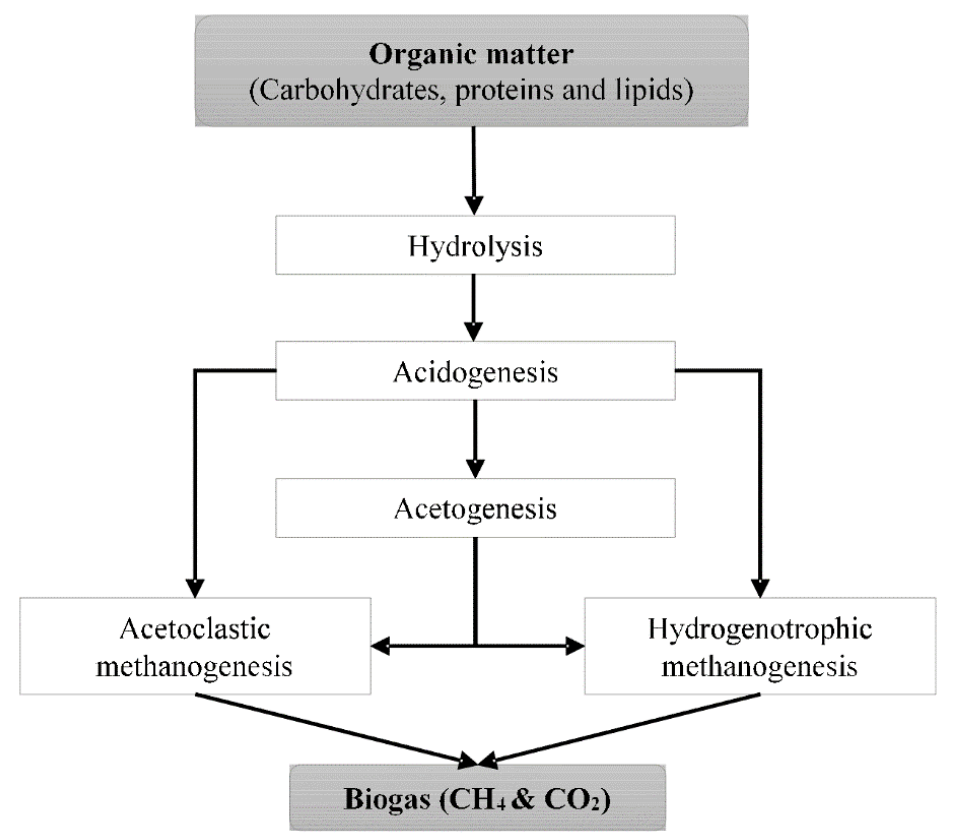

Figure 4. Anaerobic digestion process flow (Adapted from ref 7).

There are several types of reactors and mechanisms used for biogas production through anaerobic digestion. The different reactor design options and conditions have different impacts on the final process yield [34]. The main designs considered for this paper are batch, continuous and semi-continuous configurations. In addition, there are two main temperature intervals known as mesophilic and thermophilic.

In a batch $\mathrm{AD}$ process, all the substrate is placed in the reactor at the beginning and biogas production is initiated once the reactor is closed. The biogas is collected during this process until production ends. In the continuous or semi-continuous AD process, the substrate is fed in lesser amounts into the reactor at a steady flow rate while digestion and biogas production are ongoing [34].

As for temperature conditions, mesophilic conditions are usually those in the range of $30-40{ }^{\circ} \mathrm{C}$, while thermophilic are in the range of $50-60{ }^{\circ} \mathrm{C}$. The temperature range affects the types and 
activity of microorganism in an $\mathrm{AD}$ reactor. Elevated temperatures might reduce pathogens level as well as the diversity of microorganisms. However, microorganisms and enzyme have different temperature requirements for optimum activity [34,35].

Although anaerobic digestion has proven its effectiveness in treating organic matter, this has not been the case with lignocellulosic materials. This is because the composition and properties of lignocellulosic substrates hinder the ability of microorganisms and enzymes in an anaerobic digestion process to digest the organic matter. A main reason for this is due to the presence of lignin which acts as a shield for cellulose and hemicellulose $[13,31,36]$. Several studies have indicated that higher lignin contents in organic matter results in lower biogas and methane yield $[13,36]$. In addition, the crystallinity and available surface area of lignocellulosic matter hinders the ability of enzymes to reach a significant amount of areas along the surfaces of the material and thus limiting degradation abilities [36,37]. Such obstacles make the hydrolysis of cellulose and hemicellulose the rate limiting step in the anaerobic digestion of lignocellulosic biomass $[7,38]$.

Therefore, a pretreatment step is necessary to improve the hydrolysis of lignocellulosic material and thus biogas yield. 


\section{PRETREATMENT OF LIGNOCELLULOSIC BIOMASS}

Lignocellulosic substrates are organic compounds that hold an enormous potential for anaerobic digestion and methane production. However, the chemical and physical composition of lignocelluloses hinders the ability of microorganisms to breakdown these organic compounds and release biogas. However, with the right pretreatment process, the biodegradation of lignocelluloses can be improved to enhance biogas and methane production.

Several pretreatment processes have been developed over the past years to improve lignocellulosic biomass amenity to microorganism and enzymes, and enhance biogas and methane production. Pretreatment methods work in different ways to achieve desired goals. However, such methods have been observed to alter some common physical and chemical characteristics of lignocellulosic biomass such as reducing lignin and hemicelluloses contents, reducing cellulose crystallinity, reducing the degree of polymerisation and increasing accessible surface area and porosity [14,21,39]. Lignin modification and removal is particularly essential for improving methane yield as several studies have suggested that lignin concentration in a substrate is negatively proportional to methane yield $[13,40]$.

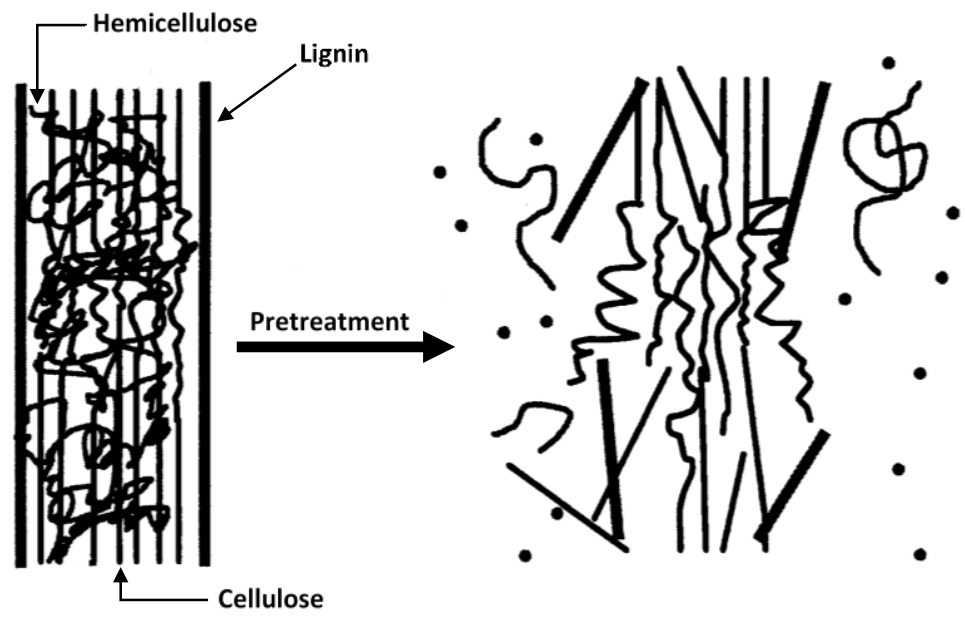

Figure 5 Schematic of pretreating lignocellulosic biomass (Adapted from Ref 41) 
Available pretreatment processes can be categorized into: physical (mechanical and irradiation), thermal, chemical, biological and combined pretreatment. Mechanical, irradiation and thermal pretreatment mainly rely on applying physical, radiation and heat energy on the lignocellulosic substrates prior to hydrolysis and AD. Biological pretreatment relies on the action of added microorganisms, fungi, and enzymes to enhance the biodegradability of lignocelluloses. Chemical pretreatment involves treatment with chemicals to enhance the anaerobic digestion process. The use of two or more different pretreatment methods is considered as a combined pretreatment method.

However, the choice of a suitable pretreatment method depends on the composition and type of the lignocellulosic materials considered as the amount of cellulose, hemicellulose and lignin varies from one type to another as presented in Table 1. In addition, a variation in the physical characteristics such as accessible surface area among different LCM might require distinct types of pretreatment processes [7]. This section provides a review of the latest and most commonly used pretreatment processes of lignocellulosic wastes for enhanced methane production.

\subsection{Biological - Enzymatic Pretreatment}

Enzymatic pretreatment of LCM involves the use of oxidative and hydrolytic enzymes often produced by bacteria and fungi [9]. This pretreatment method is gaining more interest due to its lower reaction times, low consumption of nutrition by enzymes and because enzymes are not affected by most inhibitors and microbial metabolisms [37,42]. In addition, enzymatic pretreatment does not require the use of expensive equipment for processing [43], however, high enzymes cost remains a challenge to improving the economical feasibility of enzymatic pretreatment for improved biogas production $[7,42,43]$. 
The effect of enzymes on lignocellulosic substrates depends on the type of enzymes and the composition of the substrate. This is due to enzyme specificity in terms of the reaction they catalyze $[44,45]$. For example, the enzyme laccase derived from phenoloxidasses that contains different copper ions works by catalyzing the oxidation of phenols, anilines and aromatic thiols in substrates. As a result, microbial growth is enhanced and fermentation capability is improved during anaerobic digestion. Manganese peroxidases produced by white rot fungi catalyze the oxidation of $\mathrm{Mn}^{2+}$ to $\mathrm{Mn}^{3+}$ and thus aiding the breaking lignin bonds [21]. A commonly used enzyme known as cellulase extracted from the fungus Trichoderma reesei is known for its ability to degrade insoluble cellulose [46]. Such enzymatic actions catalyze anaerobic reaction, improve the degradability of lignocelluloses, and thus enhance biogas production [47].

The activity and efficiency of enzymes is dependent on several factors including substrate type, incubation time, temperature, $\mathrm{pH}$ level and the $\mathrm{AD}$ system configuration [38].

Compared to other pretreatment methods, enzymatic pretreatment of lignocellulosic biomass to improve biogas production has not been given the same attention. However, recent studies are showing a greater attention to this pretreatment method due to the potential it holds for improving anaerobic digestion and methane production. This section presents a review of the most recent studies conducted to asses the impact of different enzymatic pretreatment methods on methane production from lignocellulosic substrates through anaerobic digestion. 
Tables 3-5 present the different studies conducted to improve biogas production from lignocellulosic material through enzymatic pretreatment. The studies are categorized based on the anaerobic digestion mechanism including mesophilic batch reactors, thermophilic batch reactors and continuous or semi-continuous reactors. Mesophilic batch reactors are more commonly used in research studies compared to other AD mechanisms. This might be due to the harsher conditions of thermophilic processes not suitable for all enzymes, and the higher costs associated with operating continuous or semi-continuous reactors.

More than 20 enzymes have been tested for enzymatic pretreatment of lignocellulosic material. Cellulase is the most commonly applied enzyme followed by $\beta$-glucosidase and Xylanase. Overall, enzymatic pretreatment seems to be a promising method to improve methane production from lignocellulosic biomass. On average, total methane yield was improved by $15 \%$ to $35 \%$ among the different substrates, pretreatment conditions and $\mathrm{AD}$ mechanisms. However, there were clear distinctions between the performance of the different substrates and AD mechanisms as discussed in the following sections.

\section{Mesophilic Batch Reactors}

The pretreatment of lignocelluloses using enzymes is most likely to be followed by a mesophilic batch AD process as presented in the literature. Such studies are presented in Table 3, which outlines the pretreatment conditions, type of enzymes used, enzymes source and the impact of the final methane yield. 
Table 3 Enzymatic pretreatment of lignocellulosic biomass for biogas production in a mesophilic batch reactor.

\begin{tabular}{|c|c|c|c|c|c|c|}
\hline Substrate & Enzymes & Enzyme Source & $\begin{array}{l}\text { Pretreatment } \\
\text { Conditions }\end{array}$ & $\begin{array}{l}\text { AD } \\
\text { Mechanism }\end{array}$ & $\begin{array}{l}\text { Methane } \\
\text { Yield }\end{array}$ & Ref \\
\hline $\begin{array}{l}\text { Damaged } \\
\text { wheat grains }\end{array}$ & $\begin{array}{l}\text { Trizyme: } \\
\text { cellulase } \\
\alpha \text {-amylase } \\
\text { protease }\end{array}$ & $/^{\mathrm{a}}$ & $37^{\circ} \mathrm{C}$ for $24 \mathrm{~h}$. & $\begin{array}{l}\text { Batch } \\
37-40^{\circ} \mathrm{C}\end{array}$ & $+7-14 \%$ & 48 \\
\hline $\begin{array}{l}\text { Pulp and } \\
\text { paper sludge }\end{array}$ & $\begin{array}{l}\text { Endoglucanase } \\
\text { Laccase }\end{array}$ & Pleurotus ostreatus & $37^{\circ} \mathrm{C}$ for $4 \mathrm{~h}$. & $\begin{array}{l}\text { Batch } \\
37^{\circ} \mathrm{C}\end{array}$ & $+34 \%$ & 49 \\
\hline $\begin{array}{l}\text { Filter paper } \\
\text { Feed } \\
\text { concentrate } \\
\text { Hay fibers } \\
\text { Grass silage } \\
\text { Corn Silage }\end{array}$ & $\begin{array}{l}\text { Trichoderma-enzyme } \\
\text { complex }\end{array}$ & Trichoderma reesei & l & $\begin{array}{l}\text { Batch } \\
19^{\circ} \mathrm{C}\end{array}$ & $+4-35 \%{ }^{b}$ & 46 \\
\hline $\begin{array}{l}\text { Willow } \\
\text { Corn Stover } \\
\text { Flax } \\
\text { Maize } \\
\text { Wheat } \\
\text { Straw } \\
\text { Hemp } \\
\text { Miscanthus }\end{array}$ & $\begin{array}{l}\text { Laccase } \\
\text { Versatile peroxidase }\end{array}$ & $\begin{array}{l}\text { Trametes versicolor } \\
\text { Bjerkandera adusta }\end{array}$ & $\begin{array}{l}30^{\circ} \mathrm{C} \text { for } 6 \mathrm{~h}- \\
24 \mathrm{~h}\end{array}$ & $\begin{array}{l}\text { Batch } \\
\text { Mesophilic }\end{array}$ & $\begin{array}{l}+33 \% \\
+15 \% \\
+14 \% \\
+6 \% \\
\text { No Change } \\
\text { No Change } \\
\text { No Change }\end{array}$ & 13 \\
\hline $\begin{array}{l}\text { Microalgal } \\
\text { biomass }\end{array}$ & $\begin{array}{l}\text { Cellulase } \\
\text { Enzyme mix: } \\
\text { Cellulase } \\
\text { glucohydrolase, } \\
\text { and xylanase }\end{array}$ & $/ a$ & $37^{\circ} \mathrm{C}$ for $6 \mathrm{~h}$ & $\begin{array}{l}\text { Batch } \\
35^{\circ} \mathrm{C}\end{array}$ & $\begin{array}{l}+8 \% \\
+15 \%\end{array}$ & 50 \\
\hline $\begin{array}{l}\text { Marine } \\
\text { macroalgae }\end{array}$ & $\begin{array}{l}\beta \text {-glucosidase, } \\
\text { pectinase, and } \\
\text { carboxy-methyl-- } \\
\text { cellulase }\end{array}$ & Aspergillus niger & $\begin{array}{l}50^{\circ} \mathrm{C} \text { for } 2 \mathrm{~h} \\
100 \mathrm{rpm}\end{array}$ & $\begin{array}{l}\text { Batch } \\
37^{\circ} \mathrm{C}\end{array}$ & $+54.6 \% \mathrm{~b}$ & 51 \\
\hline \multirow[t]{2}{*}{ Corn Cob } & $\begin{array}{l}\text { Enzymatic cocktail with } \\
\text { endo-1,3(4)-b-glucanase, } \\
\text { and collateral xylanase, } \\
\text { cellobiase, cellulase and } \\
\text { feruloyl esterase }\end{array}$ & $\begin{array}{l}\text { Humicola Insolens } \\
\text { [S57] }\end{array}$ & $30{ }^{\circ} \mathrm{C}$ for 7 days & $\begin{array}{l}\text { Batch } \\
\text { Mesophilic }\end{array}$ & $+14 \%$ & 52 \\
\hline & Ferulic acid esterases & Aspergillus terreus & & & & \\
\hline $\begin{array}{l}\text { Sugar beet } \\
\text { pulp silage } \\
\text { Vinasse }\end{array}$ & $\begin{array}{l}\text { Endoglucanase and Xylanase } \\
\text { Pectinase }\end{array}$ & $\begin{array}{l}\text { Trichoderma } \\
\text { longibrachiatum } \\
\text { / } а^{a}\end{array}$ & $50{ }^{\circ} \mathrm{C}$ for 7 days & $\begin{array}{l}\text { Batch } \\
37^{\circ} \mathrm{C}\end{array}$ & $+32.7 \%$ & 53 \\
\hline Corn stover & $\begin{array}{l}\text { Laccase } \\
\text { Manganese peroxidase } \\
\text { Versatile peroxidase }\end{array}$ & White rot fungi & $\begin{array}{l}30^{\circ} \mathrm{C} \text { for } 24 \mathrm{~h} . \\
30^{\circ} \mathrm{C} \text { for } 6 \mathrm{~h} .\end{array}$ & $\begin{array}{l}\text { Batch } \\
\text { Mesophilic }\end{array}$ & $\begin{array}{l}+25 \% \\
+17 \%\end{array}$ & 54 \\
\hline
\end{tabular}




\begin{tabular}{|c|c|c|c|c|c|c|}
\hline Substrate & Enzymes & Enzyme Source & $\begin{array}{l}\text { Pretreatment } \\
\text { Conditions }\end{array}$ & $\begin{array}{l}\text { AD } \\
\text { Mechanism }\end{array}$ & $\begin{array}{l}\text { Methane } \\
\text { Yield }\end{array}$ & Ref \\
\hline $\begin{array}{l}\text { Macroalgae: } \\
\text { Ulva rigida }\end{array}$ & $\begin{array}{l}\text { B-glucosidase and CMCase } \\
\beta \text {-glucosidase }\end{array}$ & Aspergillus niger & $\begin{array}{l}50^{\circ} \mathrm{C} \text { for } 2 \mathrm{~h} \\
100 \mathrm{rpm}\end{array}$ & $\begin{array}{l}\text { Batch } \\
37^{\circ} \mathrm{C}\end{array}$ & $\begin{array}{l}+33 \% \mathrm{~b} \\
+33 \% \mathrm{~b}\end{array}$ & 55 \\
\hline $\begin{array}{l}\text { Corn cob } \\
\text { Vine } \\
\text { trimming } \\
\text { shoots }\end{array}$ & $\begin{array}{l}\text { Enzymatic cocktail with } \\
\text { endo-1,3(4)-b-glucanase, } \\
\text { and collateral xylanase, } \\
\text { cellobiase, cellulase, and } \\
\text { feruloyl esterase }\end{array}$ & $\begin{array}{l}\text { Humicola Insolens } \\
\text { [S57] }\end{array}$ & $\begin{array}{l}40{ }^{\circ} \mathrm{C} \text { for } 3 \mathrm{hr} . \\
100^{\circ} \mathrm{C} \text { for } 10 \\
\text { min (enzyme } \\
\text { thermal } \\
\text { inactivation) } \\
10,000 \mathrm{rpm} \text { for } \\
15 \mathrm{~min}\end{array}$ & $\begin{array}{l}\text { Batch } \\
35^{\circ} \mathrm{C}\end{array}$ & $\begin{array}{l}+14.6 \% \\
+59.8 \%\end{array}$ & 56 \\
\hline \multirow[t]{2}{*}{ Switchgrass } & Lignin peroxidase (LiP) & $/{ }^{\mathrm{a}}$ & $\begin{array}{l}22{ }^{\circ} \mathrm{C} \text { for } 8 \mathrm{~h} \\
\text { Agitated at } \\
2.5 \mathrm{~Hz}\end{array}$ & $\begin{array}{l}\text { Batch } \\
35^{\circ} \mathrm{C}\end{array}$ & $+29 \%$ & 57 \\
\hline & $\begin{array}{l}\text { Manganese peroxidase } \\
(\mathrm{MnP})\end{array}$ & $/^{\mathrm{a}}$ & $\begin{array}{l}37^{\circ} \mathrm{C} \text { for } 8 \mathrm{~h} \\
\text { Agitated at } \\
2.5 \mathrm{~Hz}\end{array}$ & & $+42 \%$ & \\
\hline $\begin{array}{l}\text { Rye grain } \\
\text { silage } \\
\text { Maize silage } \\
\text { Feed residue } \\
\text { Solid cattle } \\
\text { manure } \\
\text { Grass silage }\end{array}$ & $\begin{array}{l}\text { Cellulase, hemi-cellulase, } \\
\text { xylanase, pectinase, xylan } \\
\text { esterase, pectin esterase, } \\
\text { lipase, amylase, glucosidase, } \\
\text { protease and other non- } \\
\text { identified enzymes in traces. }\end{array}$ & Fungal & $40^{\circ} \mathrm{C}$ for $1-3 \mathrm{hr}$ & $\begin{array}{l}\text { Batch } \\
35^{\circ} \mathrm{C}\end{array}$ & $\begin{array}{l}+16 \% \\
+29.8 \% \\
+54.4 \% \\
+105 \% \\
\text { No Change }\end{array}$ & 58 \\
\hline Miscanthus & $\begin{array}{l}\text { Cellobiase } \\
\text { Cellulase }\end{array}$ & $\begin{array}{l}\text { Aspergillus niger } \\
\text { Trichoderma reesei } \\
\text { [59] }\end{array}$ & $50^{\circ} \mathrm{C}$ for $24 \mathrm{~h}$ & & $\begin{array}{l}132 \mathrm{Ndm}^{3} \\
\mathrm{~kg} \mathrm{TS}^{-1} \mathrm{CH}_{4}^{\mathrm{c}}\end{array}$ & 44 \\
\hline Sida & $\begin{array}{l}\text { Cellobiase } \\
\text { Cellulase }\end{array}$ & $\begin{array}{l}\text { Aspergillus niger } \\
\text { Trichoderma reesei } \\
\text { [59] }\end{array}$ & $50^{\circ} \mathrm{C}$ for $24 \mathrm{~h}$ & & $\begin{array}{l}135 \mathrm{Ndm}^{3} \\
\mathrm{~kg} \mathrm{TS}^{-1} \mathrm{CH}_{4}^{\mathrm{c}}\end{array}$ & \\
\hline
\end{tabular}

${ }^{\text {a }}$ Source not provided by author(s)

${ }^{\mathrm{b}}$ Change in biogas

${ }^{\mathrm{c}}$ Methane yield from untreated sample not provided by author(s)

Enzymatic pretreatment of LCM showed mostly positive change in methane production through mesophilic $\mathrm{AD}$ batch reactors. Methane production improved by as low as $6 \%$ to as high as $105 \%$ while a few pretreatment attempts showed no change at all. However, from the studies reviewed there was no negative change in biogas production. The most common net increase in methane production was in the range of $14 \%$ to $35 \%$ with an average of about $25 \%$. 
The highest improvement in methane production was observed after the enzymatic pretreatment of solid cattle manure were a $105 \%$ increase in methane yield was observed. However, the same pretreatment method achieved about less than half this improvement for other substrates. The authors suggest that the high performance of solid cattle manure was due to the presence of other pretreatment methods acting prior to enzymatic treatment. These methods include animal digestion and mechanical pretreatment by animal feet stepping on the substrate and breaking it to smaller parts [58]. Such methods may have worked to increase the available surface area in the LCM and thus provided a high surface area for enzymes to work on.

Enzymatic pretreatment of vine trimming shoots improved methane production by about $60 \%$. N. Perez-Rodríguez et al [56] used high temperatures $\left(100^{\circ} \mathrm{C}\right.$ for $\left.10 \mathrm{mins}\right)$ as part of the pretreatment process for thermal inactivation of the enzymes. However, the same pretreatment conditions were less effective in pretreating corn cob, as the method used on vie trimming shoots was used on corn cob and resulted in only 15\% increase in the total methane yield. Further to this result, Perez-Rodriguez et al. [52] used an enzymatic cocktail to pretreat corn cob at $30^{\circ} \mathrm{C}$ for 7 days and only achieved a $14 \%$ improvement in total methane yield. The low impact of enzymatic pretreatment on corn cobs as opposed to vine trimming shoots, further indicates that different substrates react differently to enzymatic pretreatment.

In addition, the choice of enzymes is important in improving the final methane yield from anaerobically digested substrates. J. Frigon et al [57] demonstrated that switch grass pretreated with manganese peroxidase showed 13\% more improvement in methane yield than switch grass pretreated with lignin peroxidase, even though both enzymes work to degrade lignin. The use of 
laccase and versatile peroxidase to improve methane production from wheat straw, hemp and miscanthus did not achieve any significant change in the final methane yield after pretreatment as opposed to their success in pre-treating other substrates such as corn stover [13,54]. These results emphasise the importance of selecting the right pretreatment method to each different substrate to achieve optimum results. This requires a more detailed understanding of the substrate composition as well as the type of enzyme being used.

Many of the results obtained indicate that enzymatic pretreatment is effective in improving biogas production on a laboratory scale. However, a study by Gerhardt et al. [46] assessed the applicability and effectiveness of applying enzymatic pretreatment in agricultural biogas plants in Germany. Gerhardt et al. obtained a $4 \%$ to $35 \%$ improvement in biogas yield from different LCM including filter paper, grass silage, corn silage and hay fibers after enzymatic pretreatment using a Trichoderma enzyme complex. The average increase in biogas was around 18\% which financially justifies the use of enzyme in agricultural biogas plants ranging from small farms plants to much larger power plants.

\section{Thermophilic Batch Reactors}

The complex nature of the microbial anaerobic digestion process often results from a diverse set of microbial communities acting with an $\mathrm{AD}$ process [33]. Such microbes have different varying performance levels depending on the surrounding conditions such as temperature. For this reason, it is important to assess the impact of pretreatment and the performance microbial communities under thermophilic AD conditions. Table 4 presents some enzymatic pretreatment studies conducted under thermophilic AD conditions. 
Table 4 Enzymatic pretreatment of lignocellulosic biomass for biogas production in a thermophilic batch reactor.

\begin{tabular}{|c|c|c|c|c|c|c|}
\hline Substrate & Enzymes & Enzyme Source & $\begin{array}{l}\text { Pretreatment } \\
\text { Conditions }\end{array}$ & $\begin{array}{l}\text { AD } \\
\text { Mechanism }\end{array}$ & $\begin{array}{l}\text { Methane } \\
\text { Yield }\end{array}$ & Ref \\
\hline \multirow[t]{3}{*}{$\begin{array}{l}\text { Jose Tall } \\
\text { wheatgrass }\end{array}$} & $\begin{array}{l}\text { Cellulase } \\
\text { Hemicellulase }\end{array}$ & Humicola Insolens & $\begin{array}{l}50^{\circ} \mathrm{C} \text { for } 7 \text { days } \\
\mathrm{pH} 5.0\end{array}$ & $\begin{array}{l}\text { Batch } \\
50^{\circ} \mathrm{C}\end{array}$ & $0-31 \%$ & 30 \\
\hline & Cellulase & Trichoderma reesei & & & & \\
\hline & B-glucosidase & Aspergillus niger & & & & \\
\hline $\begin{array}{l}\text { Biofibers } \\
\text { (Digested } \\
\text { Manure) }\end{array}$ & $\begin{array}{l}\text { Laccase } \\
\text { Cellulase, } \\
\text { hemicellulase }\end{array}$ & $\rho^{\mathrm{a}}$ & $37^{\circ} \mathrm{C}$ for $20 \mathrm{~h}$ & $\begin{array}{l}\text { Batch } \\
52^{\circ} \mathrm{C}\end{array}$ & No Change & 39 \\
\hline $\begin{array}{l}\text { Forest } \\
\text { residues: tree } \\
\text { tops and } \\
\text { branches }\end{array}$ & $\begin{array}{l}\text { Laccase } \\
\text { Versatile peroxidase }\end{array}$ & $\rho^{\mathrm{a}}$ & $\begin{array}{l}37^{\circ} \mathrm{C} \text { for } 20 \mathrm{~h} \\
120 \mathrm{rpm}\end{array}$ & $\begin{array}{l}\text { Batch } \\
55^{\circ} \mathrm{C}\end{array}$ & No Change & 35 \\
\hline $\begin{array}{l}\text { Algae: } \\
\text { Spirulina } \\
\text { platensis }\end{array}$ & $\begin{array}{l}\text { Cellobiase } \\
\text { Cellulase }\end{array}$ & $\begin{array}{l}\text { Aspergillus niger } \\
\text { Trichoderma reesei }\end{array}$ & $50^{\circ} \mathrm{C}$ for $72 \mathrm{hr}$ & $\begin{array}{l}\text { Batch } \\
50^{\circ} \mathrm{C}\end{array}$ & $+24.8 \%$ & 59 \\
\hline Switchgrass & $\begin{array}{l}\text { Cellobiase } \\
\text { Cellulase }\end{array}$ & $\begin{array}{l}\text { Aspergillus niger } \\
\text { Trichoderma reesei }\end{array}$ & $50^{\circ} \mathrm{C}$ for $72 \mathrm{hr}$ & $\begin{array}{l}\text { Batch } \\
50^{\circ} \mathrm{C}\end{array}$ & $+39 \%$ & \\
\hline
\end{tabular}

${ }^{\text {a }}$ Source not provided by author(s)

Research on the use of thermophilic batch AD reactors to produce methane from enzymatically pretreated lignocelluloses showed a relatively lower success rate in improving methane production. However, two experiments by H. El-Mashad [59] on pretreated Spirulina platensis (algae) and switch grass using cellobiase and cellulose enzymes demonstrated an increase of up to $24.8 \%$ and $39 \%$ respectively. The studies were conducted under thermophilic pretreatment conditions as well. A similar study by Romano et al. [30] showed that the enzymatic pretreatment of wheat grass only impacts the final methane yield produced under thermophilic AD conditions only when enzymes are added to the first stage of a two-stage digestion system. However, there was no impact on the total methane yield if enzymatic pretreatment was applied as a separate step prior to anaerobic digestion (single stage). The study also suggested that microorganisms were already effective in carrying out digestions without the need for additional 
enzymes. However, it seems that thermophilic anaerobic digestion conditions might not have been suitable for efficient enzymatic activity.

Other researchers indicated that enzymatic pretreatment was unsuccessful in improving methane yield from a thermophilic batch reactors due to lack of enzyme access to the lignocellulosic structure $[35,39]$. The harsher conditions of thermophilic AD reactors impacted the enzymatic pretreatment of digested manure [39]. Enzymatically pretreated digested manure showed very high improvement levels in methane production under mesophilic AD conditions [58], however, there was no impact on methane production under thermophilic AD conditions [39].

Overall, cellulose and cellobiase seemed to be the most promising when used to pretreat lignocellulosic substrates under thermophilic anaerobic digestion conditions for methane production. However, improvements using theses enzymes were achieved under thermophilic pretreatment conditions and at a relatively longer pretreatment time.

\section{Mesophilic Continuous and Semi-Continuous Reactors}

In addition to the importance of the $\mathrm{AD}$ temperature levels, the configuration of the $\mathrm{AD}$ reactor is also critical to asses the applicability of pretreatment methods in improving biogas yield in large scale biogas plants. Such plants often operate with a continuous or semi-continuous configuration as continuous supplies of biomass are fed into the reactors. A few studies considered semi-continuous and continuous $\mathrm{AD}$ configurations and are presented in Table 5 below. 
Table 5 Enzymatic pretreatment of lignocellulosic biomass for biogas production in a mesophilic continuous/semi-continuous reactor.

\begin{tabular}{|c|c|c|c|c|c|c|}
\hline Substrate & Enzymes & Enzyme Source & $\begin{array}{l}\text { Pretreatment } \\
\text { Conditions }\end{array}$ & $\begin{array}{l}\text { AD } \\
\text { Mechanism }\end{array}$ & $\begin{array}{l}\text { Methane } \\
\text { Yield }\end{array}$ & Ref \\
\hline $\begin{array}{l}\text { Sugar beet } \\
\text { pulp }\end{array}$ & $\begin{array}{l}\text { Endoglucanase, xylanase } \\
\text { Pectinase }\end{array}$ & $\begin{array}{l}\text { Trichoderma } \\
\text { longibrachiatum } \\
\text { / a }\end{array}$ & $\begin{array}{l}50^{\circ} \mathrm{C} \text { for } 24 \mathrm{~h} \\
\mathrm{pH} 6.6\end{array}$ & $\begin{array}{l}\text { Semi- } \\
\text { continuous } \\
37^{\circ} \mathrm{C}\end{array}$ & $+19 \%$ & 60 \\
\hline Spent hops & $\begin{array}{l}\text { Endoglucanase, xylanase } \\
\text { Pectinase }\end{array}$ & $\begin{array}{l}\text { Trichoderma } \\
\text { longibrachiatum } \\
\text { /a }\end{array}$ & $\begin{array}{l}50^{\circ} \mathrm{C} \text { for } 24 \mathrm{~h} \\
\mathrm{pH} 6.0\end{array}$ & $\begin{array}{l}\text { Semi- } \\
\text { continuous } \\
37^{\circ} \mathrm{C}\end{array}$ & $+13 \%$ & 60 \\
\hline $\begin{array}{l}\text { Rye grain } \\
\text { silage } \\
\text { Maize silage } \\
\text { Feed residue } \\
\text { Solid cattle } \\
\text { manure } \\
\text { Grass silage }\end{array}$ & $\begin{array}{l}\text { Cellulase, hemi-cellulase, } \\
\text { xylanase, pectinase, xylan } \\
\text { esterase, pectin esterase, } \\
\text { lipase, amylase, } \\
\text { glucosidase, protease and } \\
\text { other non-identified } \\
\text { enzymes in traces [47]. }\end{array}$ & Fungal & $40^{\circ} \mathrm{C}$ for $3 \mathrm{~h}$. & $\begin{array}{l}\text { Continuous } \\
38^{\circ} \mathrm{C}\end{array}$ & $+10-17 \%$ & 61 \\
\hline Spent grains & $\begin{array}{l}\text { Multi-enzyme produced } \\
\text { by solid state fermentation } \\
\text { (SSF) }\end{array}$ & $/^{\mathrm{a}}$ & $40^{\circ} \mathrm{C}$ for 3 days & $\begin{array}{l}\text { Continuous } \\
37^{\circ} \mathrm{C}\end{array}$ & $+6.7 \%$ & 62 \\
\hline
\end{tabular}

${ }^{\text {a }}$ Source not provided by author(s)

The use of continuous/semi-continuous reactors for biogas production from enzymatically pretreated lignocelluloses is the least studied in literature. The studies reviewed included mesophilic continuous and semi-continuous reactors. Improvements in methane production from lignocellulosic substrates were in lower range of improvements (6\% to 19\%) compared to other AD mechanisms.

In comparison to batch anaerobic digestion reactors, continuous and semi-continuous $\mathrm{AD}$ reactors showed a lower performance level in improving methane production from enzymatically pretreated lignocelluloses. Two separate studies by T. Quinines et al. [58,62] demonstrated the difference in enhanced methane production from enzymatically pretreating substrates using a batch $\mathrm{AD}$ reactor and a continuous $\mathrm{AD}$ reactor. Methane production from the batch reactor was 
up 5 folds higher than that achieved from the continuous reactor for the same substrates and enzymatic pretreatment methods.

Nonetheless, continuous and semi-continuous anaerobic digestion had a high rate of success in improving total methane yield from enzymatically pretreated lignocellulosic biomass. This provides evidence that enzymatic pretreatment can be a feasible and environmentally sustainable option when adopted in large scale biogas plants.

\subsection{Biological Pretreatment (Non-Enzymatic)}

Biological pretreatment of lignocellulosic biomass mainly relies on the employment of microorganisms, fungi and enzymes to degrade LC and enhance biogas and methane production $[20,37,63]$. Lignin and hemicellulose are the most vulnerable to biological attacks as opposed to cellulose. Microorganism such as Trichoderma reesi and Trichoderma viride for example are used in pretreatment due to their capability in converting polysaccharides to monosaccharides. Fungi such as white-rot fungi has shown great effectiveness in pre-treating lignocelluloses mainly by enhancing the accessibility of cellulose and hemicellulose for enzymatic hydrolysis. $[38,63]$. Further to that biological pretreatment methods also include ensilage of the biomass for long periods of time prior to AD and microaeration, which is essentially an aerobic pretreatment step that relies on the addition of oxygen to initiate an aerobic reaction by microbes.

Biological pretreatment is viewed as an attractive pretreatment process for several reasons including its low energy requirements, mild pretreatment conditions, lack of chemical requirements and it does not result in the production of inhibitory compounds $[37,63]$. However, the rate of treatment and biogas yield from biological pretreatment remains relatively low and is 
often economically infeasible [63]. Table 6 presents several studies on the use of biological pretreatment (non-enzymatic) methods to improve the LCM methane yield.

Table 6 Impact of biological pretreatment on methane production from lignocellulosic substrates.

\begin{tabular}{|c|c|c|c|c|c|c|}
\hline Method & Substrate & Biological Source & $\begin{array}{l}\text { Pretreatment } \\
\text { Conditions }\end{array}$ & $\begin{array}{l}\text { AD } \\
\text { Mechanism }\end{array}$ & $\begin{array}{l}\text { Methane } \\
\text { Yield }\end{array}$ & Ref \\
\hline Fungal & $\begin{array}{l}\text { Japanese cedar } \\
\text { chips }\end{array}$ & Cyathus stercoreus & $\begin{array}{l}\text { Incubated for } 20 \\
\text { days at } 37^{\circ} \mathrm{C}\end{array}$ & $\begin{array}{l}\text { Batch } \\
\text { Mesophilic }\end{array}$ & $\begin{array}{l}+43 \mathrm{~mL} \\
\text { vs. } 0 \mathrm{~mL} \\
\text { control }\end{array}$ & 64 \\
\hline Fungal & $\begin{array}{l}\text { Sweet chestnut } \\
\text { leaves and hay }\end{array}$ & $\begin{array}{l}\text { Wood-rotting fungi: } \\
\text { Auricularia auricula- } \\
\text { judae }\end{array}$ & $\begin{array}{l}37{ }^{\circ} \mathrm{C} \text { for } 4-5 \text { weeks } \\
\text { in the dark }\end{array}$ & $\begin{array}{l}\text { Batch } \\
\text { Mesophilic }\end{array}$ & $+15 \%$ & 65 \\
\hline Fungal & $\begin{array}{l}\text { Sisal leaf } \\
\text { decortications } \\
\text { residue (SLDR) }\end{array}$ & $\begin{array}{l}\text { CCHT-1 strain obtained } \\
\text { from dumps of SLDR } \\
\text { and Trichoderma reesei }\end{array}$ & $\begin{array}{l}4 \text { days with CCHT- } \\
1 \text { followed by } 8 \\
\text { days with } T \text {. ressi at } \\
28{ }^{\circ} \mathrm{C}\end{array}$ & $\begin{array}{l}\text { Batch } \\
\text { Mesophilic }\end{array}$ & $+30-101 \%$ & 66 \\
\hline Fungal & Albizia Chips & $\begin{array}{l}\text { White-rot fungus: } \\
\text { Ceriporiopsis } \\
\text { subvermispora }\end{array}$ & $\begin{array}{l}\text { Incubation at } 28^{\circ} \mathrm{C} \\
\text { for } 48 \text { days }\end{array}$ & $\begin{array}{l}\text { SS-AD Batch } \\
\text { Mesophilic }\end{array}$ & + 3.7 folds & 67 \\
\hline Fungal & $\begin{array}{l}\text { Bio-waste } \\
\text { (Organic fraction } \\
\text { of household } \\
\text { waste) }\end{array}$ & Trichoderma viride & $\begin{array}{l}\text { Incubated at } 25^{\circ} \mathrm{C} \\
\text { for } 4 \text { days }\end{array}$ & $\begin{array}{l}\text { Batch } \\
\text { Thermophilic }\end{array}$ & $+400 \%$ & 68 \\
\hline $\begin{array}{l}\text { Microbial } \\
\text { consortium }\end{array}$ & Corn straw & $\begin{array}{l}\text { Yeast and cellulolytic } \\
\text { bacteria }\end{array}$ & $\begin{array}{l}\text { Microbial agent } \\
\text { dose } 0.01 \%(\mathrm{w} / \mathrm{w}) \\
20^{\circ} \mathrm{C} \text { for } 15 \text { days }\end{array}$ & $\begin{array}{l}\text { Batch } \\
\text { Mesophilic }\end{array}$ & $+75.6 \%$ & 31 \\
\hline $\begin{array}{l}\text { Microbial } \\
\text { consortium }\end{array}$ & $\begin{array}{l}\text { Pulp and paper } \\
\text { mill sludge mixed } \\
\text { with rice straw }\end{array}$ & $\begin{array}{l}\text { Microbial consortium } \\
\text { (OEM1) originating } \\
\text { from spent mushroom } \\
\text { substrate }\end{array}$ & $28^{\circ} \mathrm{C}$ for 9 days & $\begin{array}{l}\text { Batch } \\
\text { Mesophilic }\end{array}$ & $+40 \%$ & 69 \\
\hline $\begin{array}{l}\text { Microbial } \\
\text { consortium }\end{array}$ & Cotton stalk & $\begin{array}{l}\text { Thermophilic microbial } \\
\text { consortium (MC1): } \\
\text { Clostridium } \\
\text { straminisolvens CSK1, } \\
\text { Clostridium sp. FG4b, } \\
\text { Pseudoxanthomonas } \\
\text { sp. strain M1-3, } \\
\text { Brevibacilus sp. M1-5, } \\
\text { and Bordetella sp. M1-6 }\end{array}$ & $50^{\circ} \mathrm{C}$ for 8 days & $\begin{array}{l}\text { Batch } \\
\text { Mesophilic }\end{array}$ & $+136 \%$ & 70 \\
\hline $\begin{array}{l}\text { Microbial } \\
\text { consortium }\end{array}$ & $\begin{array}{l}\text { Lignocellulose of } \\
\text { municipal solid } \\
\text { waste }\end{array}$ & $\begin{array}{l}\text { Thermophilic microbial } \\
\text { consortium (MC1) }\end{array}$ & $50{ }^{\circ} \mathrm{C}$ for 4 days & $\begin{array}{l}\text { Batch } \\
\text { Mesophilic }\end{array}$ & $+105 \%$ & 71 \\
\hline $\begin{array}{l}\text { Microbial } \\
\text { consortium }\end{array}$ & Wheat straw & $\begin{array}{l}\text { G-Proteobacteria } \\
\text { Bacteroidetes } \\
\text { B-Proteobacteria } \\
\text { Firmicutes (3 types) }\end{array}$ & $37^{\circ} \mathrm{C}$ for 15 days & $\begin{array}{l}\text { Batch } \\
\text { Mesophilic }\end{array}$ & $+80.3 \%$ & 72 \\
\hline
\end{tabular}




\begin{tabular}{|c|c|c|c|c|c|c|}
\hline Method & Substrate & Biological Source & $\begin{array}{l}\text { Pretreatment } \\
\text { Conditions }\end{array}$ & $\begin{array}{l}\text { AD } \\
\text { Mechanism }\end{array}$ & $\begin{array}{l}\text { Methane } \\
\text { Yield }\end{array}$ & Ref \\
\hline & & $\begin{array}{l}\text { White-rot fungi } \\
\text { Brown-rot fungi }\end{array}$ & & & & \\
\hline $\begin{array}{l}\text { Microbial } \\
\text { consortium }\end{array}$ & Cassava residues & $\begin{array}{l}\text { Thermophilic microbial } \\
\text { consortium }\end{array}$ & $55^{\circ} \mathrm{C}$ for $12 \mathrm{~h}$ & $\begin{array}{l}\text { Batch } \\
\text { Thermophilic }\end{array}$ & $+96.6 \%$ & 73 \\
\hline $\begin{array}{l}\text { Microbial } \\
\text { consortium }\end{array}$ & $\begin{array}{l}\text { Biofibers: } \\
\text { separated from } \\
\text { digested manure, } \\
\text { maize silage and } \\
\text { industrial by- } \\
\text { product. }\end{array}$ & $\begin{array}{l}\text { Compost from garden } \\
\text { waste and fungi } \\
\text { collected from straw and } \\
\text { maize silage stored } \\
\text { outdoor for } 6 \text { months }\end{array}$ & $27^{\circ} \mathrm{C}$ for $0-20$ days & $\begin{array}{l}\text { Batch } \\
\text { Thermophilic }\end{array}$ & No change & 39 \\
\hline Ensilage & $\begin{array}{l}\text { Pineapple peel } \\
\text { waste }\end{array}$ & - & $\begin{array}{l}\text { Ensilaged for } 6 \\
\text { months }\end{array}$ & $\begin{array}{l}\text { Semi- } \\
\text { continuous } \\
\text { Mesophilic }\end{array}$ & $+55 \%$ & 74 \\
\hline Ensilage & Giant reed & - & $\begin{array}{l}\text { Ensilaged for } 60 \\
\text { days at room } \\
\text { temperature }\end{array}$ & $\begin{array}{l}\text { Batch } \\
\text { Mesophilic }\end{array}$ & $+14 \%$ & 75 \\
\hline Microaeration & Corn straw & - & $\begin{array}{l}5 \mathrm{ml} \mathrm{O}_{2} / \mathrm{g} \text { VS at } 55 \\
{ }^{\circ} \mathrm{C}\end{array}$ & $\begin{array}{l}\text { Batch } \\
\text { Mesophilic }\end{array}$ & $+16.2 \%$ & 76 \\
\hline Microaeration & Wheat straw & - & $\begin{array}{l}5 \mathrm{ml} \mathrm{O}_{2} / \mathrm{g} \mathrm{VS} \text { for } 3 \\
\text { days }\end{array}$ & $\begin{array}{l}\text { Batch } \\
\text { Thermophilic }\end{array}$ & $+7.2 \%$ & 77 \\
\hline
\end{tabular}

a increase in biogas

Biological pretreatment methods highlighted in Table 6 include the use of fungi, microbial consortiums, ensilage and micro aeration. Fungal and Microbial pretreatment showed the most promising level of improvement in total methane yield from lignocellulosic matter. As shown in the Table 6, fungal pretreatment showed up to $400 \%$ improvement in methane yield, while pretreatment with a microbial consortium increased methane yield by about $135 \%$. Micro aeration and ensilage delivered an improvement of up to $16 \%$ and $55 \%$, respectively. Overall, biological pretreatment showed a high success rate with more than $90 \%$ of studies improved methane yield by more than $13 \%$.

Fungal pretreatment was observed to improve biodegradability of lignocelluloses and increase the available fatty acids which provided better nutrients and more substrates for microorganism 
in the anaerobic digestion phase, leading to an improvement in the methane yield $[65,66,68]$. In addition, fungal pretreatment showed a low energy consumption compared to other nonbiological pretreatments [78]. Pretreatment using microbial consortiums have shown the ability to degrade lignocelluloses and reduce the content of lignin, cellulose and hemicellulose [69-72]. Zhong et al. [31] demonstrated that biologically pretreated corn straw produced 75\% more methane than untreated samples, in addition to a reduction of 5.8 to $25 \%$ in total cellulose, hemicellulose, and lignin contents. In addition, an increase in the concentration of the soluble chemical oxygen demand (SCOD) in the hydrolysates was observed after pretreatment using a microbial consortium which is directly related to increasing the biomethane yield [70]. Ensiling lignocellulosic biomass also demonstrated a potential in improving methane yield as it converts the carbohydrates to volatile fatty acids and thus enhancing methane production $[74,75]$.

Microaeration or microaerobic pretreatment has also been applied as a biological pretreatment method, where an oxygen-induced aerobic pretreatment step is used to improve the overall AD process [77]. Fu et al. [76] detected lower crystallinity levels and higher amount of amorphous celluloses in the substrate after thermophilic microaerobic pretreatment of corn straw. This resulted in more digestible cellulose and a 16\% higher methane yield after AD. The success of microaerobic pretreatment relies on the portion of oxygen supplied which was set a $5 \mathrm{ml} \mathrm{O}_{2} / \mathrm{g}$ $\mathrm{VS}_{\text {substrate }}$ in the studies reviewed. Higher amounts of oxygen have been observed to inhibit and reduce methane production $[77,79]$.

Most biological pretreatment studies reviewed were conducted under mesophilic AD conditions. However, a few experiments were conducted under thermophilic AD conditions. Results from 
the later indicate that biological pretreatment shows less consistent results under thermophilic AD conditions compared to mesophilic conditions. This is because some studies have shown almost no improvement in methane yield, while the rest have shown very high improvements such as $100 \%$ and even $400 \%$. This inconsistency implies that more studies should be conducted to assess the impact of biological pretreatment methods under thermophilic AD conditions. In addition, it not very clear how different biological pretreatment methods perform in continuously stirred anaerobic reactors. Although positive results were obtained for semi-continuous AD reactors as in Rani et al. [74] study, however, assessing the performance of continuous reactors after biological pretreatment is necessary to determine feasibility on large-scale treatment plants [66].

\subsection{Thermal Pretreatment}

In thermal pretreatment, heat is often combined with pressure to improve the biodegradability of lignocellulosic biomass. There are several different thermal pretreatment methods that can be applied. Other than the conventional means of simply using an autoclave or oven to heat up the biomass, steam explosion and liquid hot water pretreatment have been also given great attention. Steam explosion pretreatment works by exposing the biomass to high temperature and pressure for short duration time. This causes the biomass to decompose explosively. Thermal pretreatment conditions may involve temperatures as high as $260{ }^{\circ} \mathrm{C}$ and pressure that may reach 4.5 $\mathrm{MPa}[7]$.

In liquid hot water pretreatment, water is heated and maintained at liquid state through pressure $[7,80,81]$. The water is then allowed to penetrate the lignocellulosic biomass, leading to the removal of some the hemicellulose and lignin and hydrating the cellulose [81]. Liquid hot water 
thus improves cellulose accessibility and improves the hydrolysis and digestion of lignocelluloses [80]. However, undesirable phenolic compounds and furan derivatives such as furfural and hydroxymethylfurfal (HMF) can still form as a result of high temperature and which can inhibit microorganisms and reduce the content of fermentable sugars $[81,82]$.

Table 7 Impact of thermal pretreatment on methane production from lignocellulosic substrates.

\begin{tabular}{|c|c|c|c|c|c|}
\hline Method & Substrate & Pretreatment Conditions & AD Mechanism & Methane Yield & Ref \\
\hline Hyperthermophilic & $\begin{array}{l}\text { Grass } \\
\text { (Eleusine indica) }\end{array}$ & Oil bath at $80^{\circ} \mathrm{C}$ for 3 days. & $\begin{array}{l}\text { Batch } \\
\text { Thermophilic }\end{array}$ & $+46 \%$ & 82 \\
\hline Conventional heating & $\begin{array}{l}\text { Grass (Pennisetum } \\
\text { hybrid) }\end{array}$ & $\begin{array}{l}\text { Autoclave, water vapor for } \\
30 \mathrm{~min}\end{array}$ & $\begin{array}{l}\text { Batch } \\
\text { Mesophilic }\end{array}$ & $+4.5 \%$ & 83 \\
\hline Conventional heating & $\begin{array}{l}\text { Wheat straw } \\
\text { Sugarcane baggase }\end{array}$ & $121^{\circ} \mathrm{C}$ for $60 \mathrm{~min}$ & $\begin{array}{l}\text { Batch } \\
\text { Mesophilic }\end{array}$ & $\begin{array}{l}+29 \% \\
+11 \%\end{array}$ & 84 \\
\hline Conventional heating & $\begin{array}{l}\text { Barley Straw } \\
\text { Wheat Straw } \\
\text { Maize stalks } \\
\text { Rice straw }\end{array}$ & $120^{\circ} \mathrm{C}$ for $30 \mathrm{~min}$ & $\begin{array}{l}\text { Batch } \\
\text { Mesophilic }\end{array}$ & $\begin{array}{l}+40.8 \% \\
+64.3 \% \\
\text { No Change } \\
\text { No Change }\end{array}$ & 85 \\
\hline Conventional heating & $\begin{array}{l}\text { Dewatered pig manure } \\
\text { and digested sewage } \\
\text { sludge }\end{array}$ & $100^{\circ} \mathrm{C}$ for $1 \mathrm{~h}$ & Batch & $+25 \%$ & 86 \\
\hline Conventional heating & Raw excess sludge & $150^{\circ} \mathrm{C}$ for $2 \mathrm{~h}$ & $\begin{array}{l}\text { Batch } \\
\text { Mesophilic }\end{array}$ & $+223 \%$ & 4 \\
\hline Steam Explosion & Wheat straw & $\begin{array}{l}180^{\circ} \mathrm{C} \text { for } 15 \mathrm{~min}, 2 \mathrm{Mpa} \\
\text { steam }\end{array}$ & $\begin{array}{l}\text { Batch } \\
\text { Mesophilic }\end{array}$ & $+19.7 \%$ & 87 \\
\hline Steam Explosion & $\begin{array}{l}\text { Common reed } \\
\text { (Phragmites australis) }\end{array}$ & $\begin{array}{l}200^{\circ} \mathrm{C} \text { for } 15 \mathrm{~min}, 3.4 \mathrm{MPa} \\
\text { steam }\end{array}$ & $\begin{array}{l}\text { Batch } \\
\text { Mesophilic }\end{array}$ & $+89 \%$ & 88 \\
\hline Steam Explosion & $\begin{array}{l}\text { Miscanthus } \\
\text { lutarioriparius } \\
\text { (grass) }\end{array}$ & $\begin{array}{l}198{ }^{\circ} \mathrm{C} \text { for } 10 \mathrm{~min}, 1.5 \mathrm{MPa} \\
\text { steam }\end{array}$ & $\begin{array}{l}\text { Batch } \\
\text { Mesophilic }\end{array}$ & $+49.8 \%$ & 89 \\
\hline Steam Explosion & $\begin{array}{l}\text { Two-phase olive mill } \\
\text { solid waste (OMSW) } \\
\text { or alperujo }\end{array}$ & $\begin{array}{l}200{ }^{\circ} \mathrm{C} \text { for } 5 \mathrm{~min}, 1.57 \mathrm{MPa} \\
\text { steam }\end{array}$ & $\begin{array}{l}\text { Batch } \\
\text { Mesophilic }\end{array}$ & $+60.9 \%$ & 90 \\
\hline Steam Explosion & Wheat straw & $140^{\circ} \mathrm{C}$ for $60 \mathrm{~min}$ & $\begin{array}{l}\text { Batch } \\
\text { Mesophilic }\end{array}$ & $+3.6 \%$ & 91 \\
\hline Steam Explosion & Wheat straw & $200^{\circ} \mathrm{C}$ for $5 \mathrm{~min}$ & $\begin{array}{l}\text { Batch } \\
\text { Mesophilic }\end{array}$ & $+27 \%$ & 92 \\
\hline Steam Explosion & Late harvested hay & $175^{\circ} \mathrm{C}$ for $10 \mathrm{~min}$ & $\begin{array}{l}\text { Batch } \\
\text { Mesophilic }\end{array}$ & $+16 \%$ & 93 \\
\hline Steam Explosion & Japanese cedar chips & $258^{\circ} \mathrm{C}$ for $5 \mathrm{~min}, 4.51 \mathrm{MPa}$ & Batch & $+180 \mathrm{~mL} \mathrm{Ch}_{4} / \mathrm{g}$ & 78 \\
\hline
\end{tabular}




\begin{tabular}{|c|c|c|c|c|c|}
\hline Method & Substrate & Pretreatment Conditions & AD Mechanism & Methane Yield & Ref \\
\hline & & steam & Mesophilic & $\begin{array}{l}\text { vs. } 0 \mathrm{~mL} \mathrm{CH}_{4} / \mathrm{g} \\
\text { control }\end{array}$ & \\
\hline Liquid hot water & Giant reed & $190^{\circ} \mathrm{C}$ for $15 \mathrm{~min}$ & $\begin{array}{l}\text { Batch } \\
\text { Mesophilic }\end{array}$ & $+31 \%$ & 80 \\
\hline Liquid hot water & Paddy straw & $200^{\circ} \mathrm{C}$ for $15 \mathrm{~min}$ & $\begin{array}{l}\text { Batch } \\
\text { Mesophilic }\end{array}$ & $+148 \%$ & 94 \\
\hline Liquid hot water & Sugarcane press mud & $150^{\circ} \mathrm{C}$ for $20 \mathrm{~min}$ & $\begin{array}{l}\text { Batch } \\
\text { Mesophilic }\end{array}$ & $+63 \%$ & 95 \\
\hline Liquid hot water & Sunflower oil cake & $100{ }^{\circ} \mathrm{C}$ for $1-6 \mathrm{~h}$ & $\begin{array}{l}\text { Batch } \\
\text { Mesophilic }\end{array}$ & $+6.5 \%$ & 81 \\
\hline
\end{tabular}

Table 7 presents some of the main lignocellulosic thermal pretreatment methods including conventional heating, steam explosion, and liquid hot water. The studies considered showed an improvement in methane production from as low as $3.5 \%$ to as high as $223 \%$. However, most of the studies showed an improvement in the range of $10-65 \%$ under mesophilic batch AD conditions.

An elevated temperature achieved through thermal pretreatment has been observed to improve methane yield among different substrates. The improvement in methane yield has been attributed to several factors including opening up the lignocellulosic structure [84], deconstruction of lignin, decrease in hemicellulose content [95], improved glucose yield [80] and improved accessibility and degradability [86].

Optimum temperature levels varied from about $100-250{ }^{\circ} \mathrm{C}$ depending on the type of substrate and method. However, it was observed that further increase in temperature levels drastically reduced methane yield $[86-88,95]$. This may be due to the formation of complex and toxic 
compounds such as phenolic acids, furfural, HMF and in some cases melanoidins which are harmful to the microbes degrading the LCM during $\mathrm{AD}[86,95]$.

Similar to other pretreatment methods, different substrates are affected differently by the same thermal pretreatment process. For example, maize stalks and rice straw pretreated using a conventional thermal pretreatment method at a temperature of $120{ }^{\circ} \mathrm{C}$ for $30 \mathrm{~min}$ did not show any signs of improvement in methane production, as opposed to barley straw and wheat straw which showed a $40 \%$ and $64 \%$ improvement in methane yield, respectively for the same pretreatment process [85].

Looking more closely at individual thermal pretreatment methods, conventional heating had an overall improvement range of 0 to $223 \%$ which is relatively broad range. However, the improvement of $223 \%$ can be considered as a "shooting" as most improvements are almost below $60 \%$. The pretreatment temperature range for most conventional heating studies fell in the range of 100 to $120{ }^{\circ} \mathrm{C}$ which is lower than the temperature required to solubilize cellulose and hemicellulose previously discussed. Compared to other thermal pretreatment methods, conventional heating requires a longer pretreatment duration of about 30 to 60 min long which implies that this an energy intensive pretreatment method.

Steam explosion studies had harsher pretreatment conditions than conventional heating. Applying temperatures averaging around $200{ }^{\circ} \mathrm{C}$ and pressurized steam resulted in improvements in the range of 3 to $89 \%$. Such results can be considered more consistent than conventional heating which can be attributed to higher temperatures and steam pressure. This pretreatment 
method has the shortest average pretreatment duration as it achieved successful results after exposing the LCM to heat and steam for only 5 to $15 \mathrm{~min}$.

Liquid hot water pretreatment studies showed high improvement in methane yield at temperatures around 150 to $200{ }^{\circ} \mathrm{C}$ for 15 to $20 \mathrm{~min}$. LHW success has been attributed to the ability of highly pressurized and heated water to penetrate the lignocellulosic biomass, hydrating the cellulose and removing hemicellulose and lignin [95]. It can also be noticed that low temperatures and long pretreatment durations have not shown success compared to higher temperatures and shorter pretreatment durations as with the case of Fernández-Cegrí et al. [81] study in which LHW pretreatment of sunflower oil cake at $100{ }^{\circ} \mathrm{C}$ for 1 to 6 hours only achieved a $6.5 \%$ improvement in total methane yield.

Overall, thermal pretreatment methods have shown promising results in improve biogas production from LCM. Although thermal pretreatment methods rely on a source of heat energy, however, the duration of the pretreatment process is relatively short with many successful methods requiring only up to $15 \mathrm{~min}$ of heat exposure. The exposure time is critical in thermal pretreatment as maintaining high temperatures consumes a significant amount of fuel or electricity. A few studies considered the net electricity balance for thermal pretreatment methods. For example, Menadro et al. [85] measured a positive net electricity balance from the conventional pretreatment of wheat straw at $120{ }^{\circ} \mathrm{C}$ for $30 \mathrm{~min}$, highlighting the feasibility of this pretreatment process. While, Jiang et al. [80] detected a lower net energy output after pretreating giant reed using liquid hot water at $200{ }^{\circ} \mathrm{C}$ for $15 \mathrm{~min}$. The decrease in energy has been considered a result of loss of dry matter during pretreatment and the high-energy requirement of 
the pretreatment process [80]. Therefore, in this case thermal pretreatment is not a feasible pretreatment option.

Moreover, the possible formation of toxic and harmful compounds as a result of high heat exposure in thermal pretreatment requires a careful consideration of pretreatment conditions (mainly temperature and exposure time) to optimize the process and minimize the formation of such inhibitory compounds to ease the decomposition of lignocellulosic substrates. 


\subsection{Other Pretreatment Methods}

\section{Physical Pretreatment}

Physical pretreatment methods do not rely on the addition of chemicals, microorganisms or any external additives. This includes grinding, chippings, milling, and use of microwave and ultrasound radiation [37]. Comminution pretreatment techniques have shown improvements of up to $30 \%$ in methane yield from pretreated lignocellulosic substrates. Extrusion pretreatment have shown up to $70 \%$ improvement in methane yield and irradiation techniques improved methane yield by up to $24 \%$ [7]. Physical pretreatment processes require high energy input and are often considered costly [54].

\section{Chemical Pretreatment}

Chemical pretreatment involves the application of chemicals such as acids, alkalis and ionic liquids. The chemicals are used to expose substrates to harsh conditions in terms of $\mathrm{pH}$ and temperature to break down resistive bonds. Chemical pretreatment has been widely researched for ethanol production from lignocellulosic biomass, but less so for biogas production [7,19]. Positive results have been obtained through chemical pretreatment to improve biogas production from lignocelluloses. Pretreatment using acids such as $\mathrm{H}_{2} \mathrm{SO}_{4}, \mathrm{HCL}, \mathrm{HNO}_{3}$ and others have shown an improvement of 20 to $200 \%$ in methane yield from pretreated lignocellulosic substrates. Alkaline pretreated lignocelluloses using chemicals such as $\mathrm{NaOH}_{2}, \mathrm{Ca}(\mathrm{OH})_{2}$ and $\mathrm{CaO}$ have demonstrated up to 2.3 folds increase in methane yield [7]. However, chemical pretreatment methods are often expensive and may result in the formation of inhibitory compounds such as furfural [54]. 


\section{Combined Pretreatment}

The combined pretreatment of LCM refers to the combination of two or more pretreatment methods in treating the same substrate. Combined pretreatment often consists of different pretreatment methods that are applied in sequence. For example, Perez-Rodriguez et al. [52] applied physical, chemical and enzymatic pretreatment on corn cob for improved biogas production. This combined pretreatment method accomplished a $22.3 \%$ increase in total methane yield after the $\mathrm{AD}$ of corn cob. The study also assessed the performance of individual pretreatment tests with mechanical and chemical achieving about $8 \%$ improvement in methane and enzymatic improving methane yield by about $7 \%$. Such results show that combining more than one pretreatment method may lead to an overall result that is better than the cumulative sum of individual methods [52]. The reason for this improvement, is perhaps the effect on the physical structure and composition of LCM by an individual pretreatment method, which further improves the performance of the consecutive pretreatment. For example, physical pretreatment might open up the lignocellulosic structure and thus provide a larger surface area for microbes or enzymes to penetrate and work on. 


\section{DISCUSSION AND COMPARISON}

This section summarizes and presents a comparison between the different thermal and biological pretreatment methods considered in this study. The comparison is based on the pretreatment conditions such as temperature and reaction time, in addition to the impact each pretreatment method had on biomethane production. Table 8 summarizes the main pretreatment methods considered and offers a reasonable comparison that mainly focuses on average values as opposed to extremely high or low values that are less frequent.

Table 8 Comparison of different pretreatment methods.

\begin{tabular}{lllll}
\multirow{2}{*}{$\begin{array}{l}\text { Pretreament } \\
\text { Category }\end{array}$} & $\begin{array}{l}\text { Pretreatment } \\
\text { Method }\end{array}$ & \multicolumn{2}{c}{ Pretreatment Conditions } & CH4 Improvement (\%) \\
\cline { 2 - 3 } & Conventional & $100-150$ & $0.5-1 \mathrm{~h}$ & $0-60$ \\
& Steam Explosion & $150-250$ & $5-15 \mathrm{~min}$ & $5-60$ \\
Biological & Liquid Hot Water & $100-200$ & $15-20$ min & $30-60$ \\
& Fungal & $25-37$ & $2-6$ weeks & $15+{ }^{\mathrm{a}}$ \\
& Microbial & $20-55$ & $1-2$ weeks & $40-100$ \\
& Microaeration & 55 & Few days & $7-16$ \\
& Ensilage & Room temp & $2-6$ months & $15-55$ \\
& Enzymatic & $30-50$ & Few hours - few days & $15-35$ \\
\hline
\end{tabular}

${ }^{\mathrm{a}}$ Funal pretreatment showed inconsistent results and so a specific range cannot be determined

The comparison presented in Table 8 shows that in terms of methane improvement, liquid hot water and microbial pretreatment are of the most consistent and reliable thermal and biological pretreatment methods respectively. On the other hand, conventional thermal and biological microaeration pretreatment methods showed the lowest performance among the methods considered in terms of the impact on methane yield. However, there are other essential factors that should be taken into consideration when comparing pretreatment methods along the impact 
on biogas production. Such methods are mainly the pretreatment duration, temperature and energy requirements. As such parameters greatly affect the technical and economical feasibility of a pretreatment method.

In thermal pretreatment, steam explosion and LHW require the highest temperature levels that may exceed $200{ }^{\circ} \mathrm{C}$, while conventional pretreatment relies on lower average temperatures. However, the average duration range for steam explosion $(5-15 \mathrm{~min})$ is the lowest among thermal pretreatment methods. A shorter duration is desirable when handling bulk and continuous supplies and may require less energy to maintain. Conventional pretreatment methods require significantly longer pretreatment durations averaging from 30 to 60 mins. This relatively long duration might require a high-energy input to maintain.

Biological pretreatment methods are by far the slowest among other pretreatment methods. Ensilage is a very long process that may take up to 6 months and hence require considerable storage space when applied on a large scale. Fungal and microbial may take a few weeks, while microaeration may take up to a few days. However, enzymatic pretreatment has shown the most promising results in terms of pretreatment duration with many successful pretreatment attempt requiring less than 24 hours to complete and as short as 2 hours as shown in Table 3 . Therefore, with the current technologies, a trade off between short reaction times and high methane improvement is clearly evident among biological pretreatment methods. For this reason, enzymatic pretreatment is a very promising method as it has the shortest duration time but requires further process optimization to achieve higher average methane yields. 
Therefore, the selection of the optimum pretreatment method when planning and designing a biogas plant requires an advanced analysis and comparison among available pretreatment methods. The analysis should first identify possible substrates and available pretreatment technologies. This includes factoring in the pretreatment conditions (reaction time and temperature), energy requirements, capital and operational costs and the improvement in methane yield. The economic feasibility will often be the main determinant as discussed in the next chapter. 


\section{ECONOMIC FEASIBILITY}

The choice of pretreatment method will often rely on the economic feasibility of the methods considered. In pretreatment to improve biogas production, economic feasibility is often determined by measuring the net economic gain from the additional methane produced after pretreatment. If the value of this additional methane is significantly higher than the cost of pretreatment, then the pretreatment is often economically feasible. The cost of pretreatment includes the capital, operational, maintenance and material costs incurred during the pretreatment process. For thermal pretreatment, this mainly includes the cost of energy and equipment required to heat up the LCM, as well as maintenance and operational costs. However, in biological pretreatment the cost of pretreatment mainly consists of the cost of the biological additives (microbes, fungi and enzymes) or an energy supply as in the case of microaeration.

Enzymatic pretreatment is considered a relatively expensive pretreatment due to the high cost of enzymes production. However, the cost of enzymes production is expected to decrease due to technological and technical advances as well as large-scale commercial development that can be encouraged by the promising advantages of enzymatic pretreatment [38]. This is also often the case with other biological pretreatment methods. Therefore, further research on enzymatic pretreatment is encouraged to maximize the potential of this pretreatment and promote new initiatives to lower the costs of enzymes production.

The majority of studies reviewed assessed the pretreatment of LCM on a laboratory scale, while only a few considered the economical aspect of such studies. A techno-economical analyses for biogas production in the Netherlands from different waste showed that biogas production is not 
economically feasible unless subsidies are provided by the government [96]. This emphasizes the importance of pretreatment to improve the economical feasibility of biogas production. From the studies reviewed, Hjorth et al. [97] assessed the economical feasibility of mechanically pretreatment lignocelluloses. The study showed that there is a $68 \%$ net electrical surplus from the additional methane yield taking into account the energy consumed during the pretreatment. Similar results were obtained by Bruni et al. [39] after assessing the combined pretreatment of biofibers. The study found that pretreatment achieved a net gain of $68 \mathrm{kwh}$ from the additional methane yield.

On a broader scale, there have been a few studies that assessed the economic feasibility of lignocellulosic pretreatment in biogas plants. A study by Shafiei et al. [98] performed a technoeconomical evaluation of biogas production from wheat straw and paper tube residuals pretreated using steam explosion. The process evaluated was simulated using a simulation software and based experimental data from other studies. The simulation was conducted for an assumed biogas plant with a capacity of 200,000 ton/year of raw material. The study found that steam explosion pretreatment improved methane yield resulting in a $36 \%$ decrease in the manufacturing cost of methane, while increasing the capital investment by $13 \%$. A further sensitivity analysis demonstrated that a 5\% improvement achieved through pretreatment results in a $5.5 \%$ decreases in methane manufacturing costs. In addition, the most important parameters affecting the production costs were the raw material price and the methane yield [98].

A similar study also assessed the economical feasibility of different pretreatment methods including steam explosion and combined (thermal and chemical) pretreatment. Three substrates 
were considered for the study which include straw, wood and paper. The results of the study showed that the pretreatment of straw and wood is not an economically feasible option as the cost of pretreatment may equal or exceed the value of additional gas yield by up to $50 \%$. However, pretreating paper was found to be economically feasible with the value of additional methane yield exceeding the cost of pretreatment by $15 \%$. The study concluded that the cost of raw materials was the main reason for the lack of economical feasibility [99]. However, a better pretreatment method that further improves methane yield may offset the cost of raw materials.

Although there are some attempts to economically evaluate the feasibility of different pretreatment methods as a means of improving biogas production, there remains a significant shortage in more detailed economical reviews that address the economical feasibility of pretreatment at biogas plants. The need for such reviews is critical in encouraging more biogas plants and utilizing the potential of the abundant supply of lignocelluloses worldwide. 


\section{CONCLUSION}

This paper presented a review of studies on improving the biogas yield of lignocellulosic biomass through biological and thermal pretreatment. Pretreatment methods work to improve the degradability of lignocelluloses mainly by altering their physical characteristics to allow the microbes in the anaerobic digestion process to better degrade LCM. In biological pretreatment, biological components or reactions such as enzymes, microbes, fungi, ensilage and microaeration are employed to improve the biodegradability of LCM. Biological pretreatment methods are less energy intensive and require less capital cost than other pretreatment methods. However, the high cost of some biological additives such as enzymes remains an economical challenge.

Thermal pretreatment relies on heat energy and in some cases pressure to break down lignocelluloses prior to AD. However, thermal pretreatment methods require a careful process optimization as very harsh conditions may lead to the formation of toxic and harmful compounds which may negatively impact biogas production. In addition, high temperatures and long reaction times may require a high-energy input and thus may not be economically feasible.

From this review, it can be seen that more research is required to assess the impact of both biological and thermal pretreatment methods on different lignocellulosic substrates. This is because LCM differ in composition and thus react differently to pretreatment methods. Most importantly, there is also a lack of economical feasibility studies and experiments which evaluate the effectiveness of pretreatment methods on a biogas plant scale. Most studies available are conducted on a laboratory scale and therefore might not truly reflect the actual pretreatment scenarios when conducted on a larger scale. 


\section{REFERENCES}

[1] C. Sawatdeenarunat, K. Surendra, D. Takara, H. Oechsner and S. Khanal, "Anaerobic digestion of lignocellulosic biomass: Challenges and opportunities", Bioresource Technology, vol. 178, pp. 178-186, 2015.

[2] A. Limayem and S. C. Ricke, "Lignocellulosic biomass for bioethanol production: Current perspectives, potential issues and future prospects," Progress in Energy and Combustion Science, vol. 38, no. 4, pp. 449-467, 2012.

[3] X. Zhao, K. Cheng, and D. Liu, "Organosolv pretreatment of lignocellulosic biomass for enzymatic hydrolysis," Applied Microbiology and Biotechnology, vol. 82, no. 5, pp. 815827, Dec. 2009.

[4] Y. Hu, X. Hao, J. Wang, and Y. Cao, "Enhancing anaerobic digestion of lignocellulosic materials in excess sludge by bioaugmentation and pre-treatment," Waste Management, vol. 49, pp. 55-63, 2016.

[5] S. Behera, R. Arora, N. Nandhagopal, and S. Kumar, "Importance of chemical pretreatment for bioconversion of lignocellulosic biomass," Renewable and Sustainable Energy Reviews, vol. 36, pp. 91-106, 2014.

[6] Y. Sun and J. Cheng, "Hydrolysis of lignocellulosic materials for ethanol production: a review," Bioresource Technology, vol. 83, no. 1, pp. 1-11, 2002.

[7] Y. Zheng, J. Zhao, F. Xu, and Y. Li, "Pretreatment of lignocellulosic biomass for enhanced biogas production," Progress in Energy and Combustion Science, vol. 42, pp. 35-53, 2014.

[8] B. Yang and C. E. Wyman, "Pretreatment: the key to unlocking low-cost cellulosic ethanol," Biofuels, Bioproducts and Biorefining, vol. 2, no. 1, pp. 26-40, 2008.

[9] G. Y. Mtui, Recent advances in pretreatment of lignocellulosic wastes and production of value added products. African Journal of Biotechnology, 8(8), 2009.

[10] H. Kobayashi and A. Fukuoka, "Synthesis and utilisation of sugar compounds derived from lignocellulosic biomass," Green Chemistry, vol. 15, no. 7, p. 1740, 2013.

[11] S. Nanda, R. Azargohar, A. K. Dalai, and J. A. Kozinski, "An assessment on the sustainability of lignocellulosic biomass for biorefining," Renewable and Sustainable Energy Reviews, vol. 50, pp. 925-941, 2015.

[12] S. H. Mood, A. H. Golfeshan, M. Tabatabaei, G. S. Jouzani, G. H. Najafi, M. Gholami, and M. Ardjmand, "Lignocellulosic biomass to bioethanol, a comprehensive review with a focus on pretreatment," Renewable and Sustainable Energy Reviews, vol. 27, pp. 77-93, 2013.

[13] M. Schroyen, H. Vervaeren, H. Vandepitte, S. W. V. Hulle, and K. Raes, "Effect of enzymatic pretreatment of various lignocellulosic substrates on production of phenolic compounds and biomethane potential," Bioresource Technology, vol. 192, pp. 696-702, 2015.

[14] R. Chandra, H. Takeuchi, and T. Hasegawa, "Methane production from lignocellulosic agricultural crop wastes: A review in context to second generation of biofuel production," Renewable and Sustainable Energy Reviews, vol. 16, no. 3, pp. 1462-1476, 2012.

[15] C. Sánchez, "Lignocellulosic residues: Biodegradation and bioconversion by fungi," Biotechnology Advances, vol. 27, no. 2, pp. 185-194, 2009. 
[16] Harmsen, P. F. H.; Huijgen, W.; Bermudez, L.; Bakker, R. Wageningen UR Food \& Biobased Research, 2010. Report 1184, ISBN 9789085857570; pp. 1-54.

[17] B. Medronho, A. Romano, M. G. Miguel, L. Stigsson, and B. Lindman, "Rationalizing cellulose (in)solubility: reviewing basic physicochemical aspects and role of hydrophobic interactions," Cellulose, vol. 19, no. 3, pp. 581-587, Jun. 2012.

[18] B. C. B. Lindman, G. Karlström, and L. Stigsson, "On the mechanism of dissolution of cellulose," Journal of Molecular Liquids, vol. 156, no. 1, pp. 76-81, 2010.

[19]A. Hendriks and G. Zeeman, "Pretreatments to enhance the digestibility of lignocellulosic biomass," Bioresource Technology, vol. 100, no. 1, pp. 10-18, 2009.

[20] M. Rollini, C. Sambusiti, A. Musatti, E. Ficara, I. Retinò, and F. Malpei, "Comparative performance of enzymatic and combined alkaline-enzymatic pretreatments on methane production from ensiled sorghum forage," Bioprocess and Biosystems Engineering, vol. 37, no. 12, pp. 2587-2595, 2014.

[21] R. Ravindran and A. K. Jaiswal, "A comprehensive review on pre-treatment strategy for lignocellulosic food industry waste: Challenges and opportunities," Bioresource Technology, vol. 199, pp. 92-102, 2016.

[22] X. Ge, F. Xu, and Y. Li, "Solid-state anaerobic digestion of lignocellulosic biomass: Recent progress and perspectives," Bioresource Technology, vol. 205, pp. 239-249, 2016.

[23] Y. Hadar, "Sources for Lignocellulosic Raw Materials for the Production of Ethanol," Lignocellulose Conversion, pp. 21-38, 2013.

[24] P. A. M. Claassen, J. B. V. Lier, A. M. L. Contreras, E. W. J. V. Niel, L. Sijtsma, A. J. M. Stams, S. S. D. Vries, and R. A. Weusthuis, "Utilisation of biomass for the supply of energy carriers," Applied Microbiology and Biotechnology, vol. 52, no. 6, pp. 741-755, 1999.

[25] A. K. Chandel and O. V. Singh, "Weedy lignocellulosic feedstock and microbial metabolic engineering: advancing the generation of 'Biofuel'," Applied Microbiology and Biotechnology, vol. 89, no. 5, pp. 1289-1303, 2010.

[26] M. Galbe and G. Zacchi, "Pretreatment: The key to efficient utilization of lignocellulosic materials," Biomass and Bioenergy, vol. 46, pp. 70-78, 2012.

[27] [J.-P. Lange, "Lignocellulose Conversion: An Introduction to Chemistry, Process and Economics," Catalysis for Renewables, pp. 21-51.

[28] P. Mckendry, "Energy production from biomass (part 2): conversion technologies," Bioresource Technology, vol. 83, no. 1, pp. 47-54, 2002.

[29] G. Brodeur, E. Yau, K. Badal, J. Collier, K. B. Ramachandran, and S. Ramakrishnan, "Chemical and Physicochemical Pretreatment of Lignocellulosic Biomass: A Review," Enzyme Research, vol. 2011, pp. 1-17, 2011.

[30]R. T. Romano, R. Zhang, S. Teter, and J. A. Mcgarvey, "The effect of enzyme addition on anaerobic digestion of Jose Tall Wheat Grass," Bioresource Technology, vol. 100, no. 20, pp. 4564-4571, 2009.

[31]W. Zhong, Z. Zhang, Y. Luo, S. Sun, W. Qiao, and M. Xiao, "Effect of biological pretreatments in enhancing corn straw biogas production," Bioresource Technology, vol. 102, no. 24, pp. 11177-11182, 2011.

[32] C. Mao, Y. Feng, X. Wang, and G. Ren, "Review on research achievements of biogas from anaerobic digestion," Renewable and Sustainable Energy Reviews, vol. 45, pp. 540-555, 2015. 
[33]L. Appels, J. Lauwers, J. Degrève, L. Helsen, B. Lievens, K. Willems, J. V. Impe, and R. Dewil, "Anaerobic digestion in global bio-energy production: Potential and research challenges," Renewable and Sustainable Energy Reviews, vol. 15, no. 9, pp. 4295-4301, 2011.

[34]E.S. Moglia. (2008). Enzymatic pre-treatment of cellulose rich biomasses for use in the biogas process.

[35]C. Kvillborn. (2013). Enzymatic Pretreatment of Lignocellulose Rich Waste for Improved Biogas Production.

[36]A. Teghammar, J. Yngvesson, M. Lundin, M. J. Taherzadeh, and I. S. Horváth, "Pretreatment of paper tube residuals for improved biogas production," Bioresource Technology, vol. 101, no. 4, pp. 1206-1212, 2010.

[37] M. Shafiei, R. Kumar, and K. Karimi, "Pretreatment of Lignocellulosic Biomass," Lignocellulose-Based Bioproducts Biofuel and Biorefinery Technologies, pp. 85$154,2015$.

[38] W. Parawira, "Enzyme research and applications in biotechnological intensification of biogas production," Critical Reviews in Biotechnology, vol. 32, no. 2, pp. 172-186, 2011.

[39] E. Bruni, A. P. Jensen, and I. Angelidaki, "Comparative study of mechanical, hydrothermal, chemical and enzymatic treatments of digested biofibers to improve biogas production," Bioresource Technology, vol. 101, no. 22, pp. 8713-8717, 2010.

[40] V. Dandikas, H. Heuwinkel, F. Lichti, J. Drewes, and K. Koch, "Correlation between biogas yield and chemical composition of energy crops," Bioresource Technology, vol. 174, pp. 316-320, 2014.

[41]N. Mosier, "Features of promising technologies for pretreatment of lignocellulosic biomass," Bioresource Technology, vol. 96, no. 6, pp. 673-686, 2005.

[42] S. Wei, "The application of biotechnology on the enhancing of biogas production from lignocellulosic waste," Applied Microbiology and Biotechnology, vol. 100, no. 23, pp. 98219836, 2016.

[43]F. Ometto, G. Quiroga, P. Pšenička, R. Whitton, B. Jefferson, and R. Villa, "Impacts of microalgae pre-treatments for improved anaerobic digestion: Thermal treatment, thermal hydrolysis, ultrasound and enzymatic hydrolysis," Water Research, vol. 65, pp. 350-361, 2014.

[44]K. Michalska, M. Bizukojć, and S. Ledakowicz, "Pretreatment of energy crops with sodium hydroxide and cellulolytic enzymes to increase biogas production," Biomass and Bioenergy, vol. 80, pp. 213-221, 2015.

[45] J. V. Dyk and B. Pletschke, "A review of lignocellulose bioconversion using enzymatic hydrolysis and synergistic cooperation between enzymes-Factors affecting enzymes, conversion and synergy," Biotechnology Advances, vol. 30, no. 6, pp. 1458-1480, 2012.

[46] M. Gerhardt, V. Pelenc, and M. Bäuml, "Application of hydrolytic enzymes in the agricultural biogas production: Results from practical applications in Germany," Biotechnology Journal, vol. 2, no. 12, pp. 1481-1484, 2007.

[47] M. Ploechl, A. Hilse, M. Heiermann, T.S. Quinones, J. Budde \& A. Prochnow, Application of hydrolytic enzymes for improving biogas feedstock fluidity. Agricultural Engineering International: CIGR Journal, 2010. 
[48] V. Sonakya, N. Raizada \& V.C. Kalia, Microbial and enzymatic improvement of anaerobic digestion of waste biomass. Biotechnology letters, 23(18), 1463-1466, 2001.

[49]L. Yunqin, W. Dehan, and W. Lishang, "Biological pretreatment enhances biogas production in the anaerobic digestion of pulp and paper sludge," Waste Management \& Research, vol. 28, no. 9, pp. 800-810, Oct. 2010.

[50]F. Passos, A. Hom-Diaz, P. Blanquez, T. Vicent, and I. Ferrer, "Improving biogas production from microalgae by enzymatic pretreatment," Bioresource Technology, vol. 199, pp. 347351, 2016.

[51]R. Karray, M. Hamza, and S. Sayadi, "Production and characterization of enzymatic cocktail produced by Aspergillus niger using green macroalgae as nitrogen source and its application in the pre-treatment for biogas production from Ulva rigida," Bioresource Technology, vol. 216, pp. 622-628, 2016.

[52]N. Pérez-Rodríguez, D. García-Bernet, and J. Domínguez, "Extrusion and enzymatic hydrolysis as pretreatments on corn cob for biogas production," Renewable Energy, vol. 107, pp. 597-603, 2017.

[53]K. Ziemiński and M. Kowalska-Wentel, "Effect of enzymatic pretreatment on anaerobic codigestion of sugar beet pulp silage and vinasse," Bioresource Technology, vol. 180, pp. 274$280,2015$.

[54] M. Schroyen, H. Vervaeren, S. W. V. Hulle, and K. Raes, "Impact of enzymatic pretreatment on corn stover degradation and biogas production," Bioresource Technology, vol. 173, pp. 59-66, 2014.

[55]R. Karray, M. Hamza, and S. Sayadi, "Evaluation of ultrasonic, acid, thermo-alkaline and enzymatic pre-treatments on anaerobic digestion of Ulva rigida for biogas production," Bioresource Technology, vol. 187, pp. 205-213, 2015.

[56]N. Pérez-Rodríguez, D. García-Bernet, and J. Domínguez, "Effects of enzymatic hydrolysis and ultrasounds pretreatments on corn cob and vine trimming shoots for biogas production," Bioresource Technology, vol. 221, pp. 130-138, 2016.

[57] J.-C. Frigon, P. Mehta, and S. R. Guiot, "Impact of mechanical, chemical and enzymatic pretreatments on the methane yield from the anaerobic digestion of switchgrass," Biomass and Bioenergy, vol. 36, pp. 1-11, 2012.

[58] T. S Quiñones, M. Plöchl, J. Budde \& M. Heiermann, Do hydrolytic enzymes enhance methane formation of agricultural feedstock. Internationale Wissenschaftstagung Biogas Science 137, 2009.

[59]H. M. El-Mashad, "Biomethane and ethanol production potential of Spirulina platensis algae and enzymatically saccharified switchgrass," Biochemical Engineering Journal, vol. 93, pp. 119-127, 2015.

[60]K. Ziemiński, I. Romanowska, and M. Kowalska, "Enzymatic pretreatment of lignocellulosic wastes to improve biogas production," Waste Management, vol. 32, no. 6, pp. 1131-1137, 2012.

[61]T. S. C. A. Quiñones, M. Plöchl, J. Budde, and M. Heiermann, "Enhanced Methane Formation through Application of Enzymes: Results from Continuous Digestion Tests," Energy \& Fuels, vol. 25, no. 11, pp. 5378-5386, 2011.

[62] G. Bochmann, T. Herfellner, F. Susanto, F. Kreuter, and G. Pesta, “Application of enzymes in anaerobic digestion," Water Science \& Technology, vol. 56, no. 10, p. 29, 2007. 
[63]M. J. Taherzadeh and K. Karimi, "Pretreatment of Lignocellulosic Wastes to Improve Ethanol and Biogas Production: A Review," International Journal of Molecular Sciences, vol. 9, no. 9, pp. 1621-1651, Jan. 2008.

[64]Z.-H. Hu, Z.-B. Yue, H.-Q. Yu, S.-Y. Liu, H. Harada, and Y.-Y. Li, "Mechanisms of microwave irradiation pretreatment for enhancing anaerobic digestion of cattail by rumen microorganisms," Applied Energy, vol. 93, pp. 229-236, 2012.

[65]T. C. A. C. A. Mackul'ak, J. Prousek, L. Švorc, and M. Drtil, "Increase of biogas production from pretreated hay and leaves using wood-rotting fungi," Chemical Papers, vol. 66, no. 7, Jan. 2012.

[66] M. Muthangya, A. M. Mshandete, and A. K. Kivaisi, "Two-Stage Fungal Pre-Treatment for Improved Biogas Production from Sisal Leaf Decortication Residues," International Journal of Molecular Sciences, vol. 10, no. 11, pp. 4805-4815, Jun. 2009.

[67]X. Ge, T. Matsumoto, L. Keith, and Y. Li, "Fungal Pretreatment of Albizia Chips for Enhanced Biogas Production by Solid-State Anaerobic Digestion," Energy \& Fuels, vol. 29, no. 1, pp. 200-204, 2015.

[68] A. O. Wagner, T. Schwarzenauer, and P. Illmer, "Improvement of methane generation capacity by aerobic pre-treatment of organic waste with a cellulolytic Trichoderma viride culture," Journal of Environmental Management, vol. 129, pp. 357-360, 2013.

[69] Y. Lin, J. Liang, C. Zeng, D. Wang, and H. Lin, "Anaerobic digestion of pulp and paper mill sludge pretreated by microbial consortium OEM1 with simultaneous degradation of lignocellulose and chlorophenols," Renewable Energy, vol. 108, pp. 108-115, 2017.

[70] X. Yuan, L. Ma, B. Wen, D. Zhou, M. Kuang, W. Yang, and Z. Cui, "Enhancing anaerobic digestion of cotton stalk by pretreatment with a microbial consortium (MC1)," Bioresource Technology, vol. 207, pp. 293-301, 2016.

[71]X. Yuan, B. Wen, X. Ma, W. Zhu, X. Wang, S. Chen, and Z. Cui, "Enhancing the anaerobic digestion of lignocellulose of municipal solid waste using a microbial pretreatment method," Bioresource Technology, vol. 154, pp. 1-9, 2014.

[72] C. Zhong, C. Wang, F. Wang, H. Jia, P. Wei, and Y. Zhao, "Enhanced biogas production from wheat straw with the application of synergistic microbial consortium pretreatment," RSC Adv., vol. 6, no. 65, pp. 60187-60195, 2016.

[73]Q. Zhang, J. He, M. Tian, Z. Mao, L. Tang, J. Zhang, and H. Zhang, "Enhancement of methane production from cassava residues by biological pretreatment using a constructed microbial consortium," Bioresource Technology, vol. 102, no. 19, pp. 8899-8906, 2011.

[74]D. Rani and K. Nand, "Ensilage of pineapple processing waste for methane generation," Waste Management, vol. 24, no. 5, pp. 523-528, 2004.

[75] S. Liu, F. Xu, X. Ge, and Y. Li, "Comparison between ensilage and fungal pretreatment for storage of giant reed and subsequent methane production," Bioresource Technology, vol. 209, pp. 246-253, 2016.

[76]S.-F. Fu, F. Wang, X.-Z. Yuan, Z.-M. Yang, S.-J. Luo, C.-S. Wang, and R.-B. Guo, “The thermophilic $\left(55^{\circ} \mathrm{C}\right)$ microaerobic pretreatment of corn straw for anaerobic digestion," Bioresource Technology, vol. 175, pp. 203-208, 2015.

[77]P. Tsapekos, P. Kougias, S. Vasileiou, G. Lyberatos, and I. Angelidaki, "Effect of microaeration and inoculum type on the biodegradation of lignocellulosic substrate," Bioresource Technology, vol. 225, pp. 246-253, 2017. 
[78]H. Take, Y. Andou, Y. Nakamura, F. Kobayashi, Y. Kurimoto, and M. Kuwahara, "Production of methane gas from Japanese cedar chips pretreated by various delignification methods," Biochemical Engineering Journal, vol. 28, no. 1, pp. 30-35, 2006.

[79] Amin, F. R., Khalid, H.; Zhang, H.; Rahman, S. U.; Zhang, R.; Liu, G.; Chen, C. AMB Express, 7,72, 2017

[80]D. Jiang, X. Ge, Q. Zhang, and Y. Li, "Comparison of liquid hot water and alkaline pretreatments of giant reed for improved enzymatic digestibility and biogas energy production," Bioresource Technology, vol. 216, pp. 60-68, 2016.

[81] V. Fernández-Cegrí, M. Á. D. L. Rubia, F. Raposo, and R. Borja, "Effect of hydrothermal pretreatment of sunflower oil cake on biomethane potential focusing on fibre composition," Bioresource Technology, vol. 123, pp. 424-429, 2012.

[82] C. Rodriguez, A. Alaswad, K. Benyounis, and A. Olabi, "Pretreatment techniques used in biogas production from grass," Renewable and Sustainable Energy Reviews, vol. 68, pp. 1193-1204, 2017.

[83]L. Li, X. Kong, F. Yang, D. Li, Z. Yuan, and Y. Sun, "Biogas Production Potential and Kinetics of Microwave and Conventional Thermal Pretreatment of Grass," Applied Biochemistry and Biotechnology, vol. 166, no. 5, pp. 1183-1191, 2011.

[84] S. Bolado-Rodríguez, C. Toquero, J. Martín-Juárez, R. Travaini, and P. A. García-Encina, "Effect of thermal, acid, alkaline and alkaline-peroxide pretreatments on the biochemical methane potential and kinetics of the anaerobic digestion of wheat straw and sugarcane bagasse," Bioresource Technology, vol. 201, pp. 182-190, 2016.

[85] S. Menardo, G. Airoldi, and P. Balsari, "The effect of particle size and thermal pre-treatment on the methane yield of four agricultural by-products," Bioresource Technology, vol. 104, pp. 708-714, 2012.

[86]R. Rafique, T. G. Poulsen, A.-S. Nizami, Z.-U.-Z. Asam, J. D. Murphy, and G. Kiely, "Effect of thermal, chemical and thermo-chemical pre-treatments to enhance methane production," Energy, vol. 35, no. 12, pp. 4556-4561, 2010.

[87] A. Bauer, P. Bösch, A. Friedl, and T. Amon, "Analysis of methane potentials of steamexploded wheat straw and estimation of energy yields of combined ethanol and methane production," Journal of Biotechnology, vol. 142, no. 1, pp. 50-55, 2009.

[88] J. Lizasoain, M. Rincón, F. Theuretzbacher, R. Enguídanos, P. J. Nielsen, A. Potthast, T. Zweckmair, A. Gronauer, and A. Bauer, "Biogas production from reed biomass: Effect of pretreatment using different steam explosion conditions," Biomass and Bioenergy, vol. 95, pp. 84-91, 2016.

[89] C. Li, G. Liu, I. A. Nges, and J. Liu, "Enhanced biomethane production from Miscanthus lutarioriparius using steam explosion pretreatment," Fuel, vol. 179, pp. 267-273, 2016.

[90]B. C. A. Rincón, G. Rodríguez-Gutiérrez, L. Bujalance, J. Fernández-Bolaños, and R. Borja, "Influence of a steam-explosion pre-treatment on the methane yield and kinetics of anaerobic digestion of two-phase olive mil solid waste or alperujo," Process Safety and Environmental Protection, vol. 102, pp. 361-369, 2016.

[91]F. Theuretzbacher, J. Lizasoain, C. Lefever, M. K. Saylor, R. Enguidanos, N. Weran, A. Gronauer, and A. Bauer, "Steam explosion pretreatment of wheat straw to improve methane yields: Investigation of the degradation kinetics of structural compounds during anaerobic digestion," Bioresource Technology, vol. 179, pp. 299-305, 2015. 
[92]L. Ferreira, P. Nilsen, F. Fdz-Polanco, and S. Pérez-Elvira, "Biomethane potential of wheat straw: Influence of particle size, water impregnation and thermal hydrolysis," Chemical Engineering Journal, vol. 242, pp. 254-259, 2014.

[93]A. Bauer, J. Lizasoain, F. Theuretzbacher, J. W. Agger, M. Rincón, S. Menardo, M. K. Saylor, R. Enguídanos, P. J. Nielsen, A. Potthast, T. Zweckmair, A. Gronauer, and S. J. Horn, "Steam explosion pretreatment for enhancing biogas production of late harvested hay," Bioresource Technology, vol. 166, pp. 403-410, 2014.

[94] A. Trivedi, V.K. Vijay, and R. Chandra, Proceedings of the First International Conference on Recent Advances in Bioenergy Research, Kapurthala, India, 2016; pp. 15-22.

[95]L. M. L. C. B. González, I. P. Reyes, J. Dewulf, J. Budde, M. Heiermann, and H. Vervaeren, "Effect of liquid hot water pre-treatment on sugarcane press mud methane yield," Bioresource Technology, vol. 169, pp. 284-290, 2014.

[96] S. A. Gebrezgabher, M. P. Meuwissen, B. A. Prins, and A. G. O. Lansink, "Economic analysis of anaerobic digestion-A case of Green power biogas plant in The Netherlands," NJAS - Wageningen Journal of Life Sciences, vol. 57, no. 2, pp. 109-115, 2010.

[97] M. Hjorth, K. Gränitz, A. P. Adamsen, and H. B. Møller, "Extrusion as a pretreatment to increase biogas production," Bioresource Technology, vol. 102, no. 8, pp. 4989-4994, 2011.

[98]M. Shafiei, M. M. Kabir, H. Zilouei, I. S. Horváth, and K. Karimi, "Techno-economical study of biogas production improved by steam explosion pretreatment," Bioresource Technology, vol. 148, pp. 53-60, 2013.

[99]P.B. Odhner, I.S. Horvath, M. M. Kabir, and A. Schabbaeur, Biogas from Lignocellulosic Biomass; Svenskt Gastekniskt Center AB: Malmö, Sweden, 2012; Rapport SGC 247, ISRN SGC-R-247-SE. 